\title{
Downward fluxes of sinking particulate matter in the deep Ionian Sea (NESTOR site), eastern Mediterranean: seasonal and interannual variability
}

\author{
S. Stavrakakis, A. Gogou, E. Krasakopoulou, A. P. Karageorgis, H. Kontoyiannis, G. Rousakis, D. Velaoras, \\ L. Perivoliotis, G. Kambouri, I. Stavrakaki, and V. Lykousis \\ Hellenic Centre for Marine Research (HCMR), Institute of Oceanography, 46.7 km Athens-Sounio Av., \\ 19013 Anavyssos, Greece
}

Correspondence to: S. Stavrakakis (stavrak@hcmr.gr) and A. Gogou (agogou@hcmr.gr)

Received: 30 November 2012 - Published in Biogeosciences Discuss.: 10 January 2013

Revised: 14 August 2013 - Accepted: 19 August 2013 - Published: 12 November 2013

\begin{abstract}
In order to assess seasonal and interannual variability in the export of particulate matter and its main constituents, sediment traps were deployed at five successive depths from February 2006 to March 2010 in the deepest basin of the Mediterranean (SE Ionian Sea, NESTOR site). The average total mass fluxes were $66,58,54,34$, and $52 \mathrm{mg} \mathrm{m}^{-2} \mathrm{~d}^{-1}$, at 700, 1200, 2000, 3200, and $4300 \mathrm{~m}$, respectively. The temporal variations of the mass flux showed similar seasonal signal at all sampling depths with higher values in spring-summer and lower in autumn-winter. Changes in the main constituents of the mass flux (organic carbon, carbonates, opal, and lithogenic matter) largely followed the same temporal variability with total mass flux, revealing mechanisms of rapid vertical (top-down) transport from $700 \mathrm{~m}$ down to $4300 \mathrm{~m}$ depth. Lateral inputs at the deepest trap are probably of importance, attributed to the influence of the deep Adriatic water, characterized by relatively higher turbidity than overlying water masses. Two major processes seem to control the seasonal mass flux variability: (a) primary productivity at the euphotic zone; and (b) episodic dust input events. Primary productivity shows two maxima during late winter/early spring and late spring/summer, as witnessed by the organic carbon, carbonate, and opal fluxes in the mesopelagic and bathypelagic layers, whereas the influence of dust inputs is evidenced by enhanced lithogenic fluxes occurring during spring and summer. The interannual variability generally shows a gradual increase of fluxes during the time frame of the experiment. Both seasonal and interannual variability of mass flux are associated with varia-
\end{abstract}

tions in the intensity and position of the neighboring Pelops anticyclonic gyre, which appears to affect the upwelling of intermediate, nutrient-rich waters and subsequently the surface productivity. Combination of estimated satellite and algorithm-generated primary production data for the Ionian Sea, calculated POC fluxes out of the euphotic layer and POC fluxes measured by sediment traps at the mesopelagic and bathypelagic layers of NESTOR site during our $4 \mathrm{yr}$ experiment, reveal that only a small portion of primary production $(0.46 \%)$ reaches at $3200 \mathrm{~m}$, corresponding to a mean annual carbon export of $1.12 \mathrm{~g} \mathrm{C} \mathrm{m}^{-2} \mathrm{yr}^{-1}$.

\section{Introduction}

Formation and sinking of particulate matter drive the biological carbon pump via export and sedimentation of organic matter from the surface mixed layer to the deep ocean and sediments (reviewed by Honjo et al., 2008). Biotic processes that form, change, transport, and remineralize particulate organic carbon, opal, calcium carbonate, and other minor chemical species in the water column are central to the ocean's biogeochemical cycles and are of fundamental importance to the global carbon cycle (Armstrong et al., 2002; Broecker and Peng, 1982; Lee et al., 2009; Passow, 2004; Volk and Hoffert, 1985).

As the environmental and oceanographic conditions can change substantially over time, time-series studies of particle fluxes as recorded by sediment traps have proven valuable for 
biogeochemical studies in the world ocean (Buesseler et al., 2007; Buesseler and Boyd, 2009; Conte et al., 2001; Fabres et al., 2008; Haake et al., 1993; Honda et al., 1997; Honjo et al., 2008; Ittekkot et al., 1992; Karl et al., 1996, 2001; Lee et al., 2009; Martin et al., 2010; Sanchez-Vidal et al., 2005; Takahashi et al., 2000, 2002; Wong et al., 1999; Zúñiga et al., 2007). The fraction of organic matter that sinks out from the upper mixed layer of the ocean is, among other factors, determined by the sinking velocity and microbial remineralization rates of marine aggregates, fecal pellets and carcasses of different organisms, feeding the vertical flux of organic material. During intense bloom periods, phytoplankton can contribute a significant part of the flux through direct sedimentation, without being grazed by zooplankton. Overall, open ocean flux of organic carbon at $2000 \mathrm{~m}$ rarely exceeds $0.1-2 \%$ of the net primary production measured at surface layers (Lampitt and Antia, 1997). Processes of particle dissolution and remineralization are very intense during transport in the water column and the sea floor, and most particulate organic carbon is returned to inorganic form and redistributed in the water column, determining the surface concentration of $\mathrm{CO}_{2}$, and hence the rate at which the ocean can absorb $\mathrm{CO}_{2}$ from the atmosphere. The ability to predict quantitatively the depth profile of carbon remineralization is therefore critical to global change studies (Siegenthaler and Sarmiento, 1993).

The Mediterranean Sea is a marginal sea which has been suggested to play an important role in the drawdown of anthropogenic carbon (Aït-Ameur and Goyet, 2006; Álvarez et al., 2005). Recently published anthropogenic $\mathrm{CO}_{2}\left(\mathrm{C}_{\text {ant }}\right)$ estimates (Krasakopoulou et al., 2011; Schneider et al., 2010; Touratier and Goyet, 2011) showed that the $\mathrm{C}_{\mathrm{ant}}$ inventory for the Mediterranean is $\sim 1.7 \operatorname{PgC}$, thus indicating that this marginal sea has higher $\mathrm{C}_{\mathrm{ant}}$ concentrations than the global average, mainly determined by the surprisingly high anthropogenic carbon content of the eastern Mediterranean Sea (Sabine and Tanhua, 2010; Schneider et al., 2010). The strong uptake of anthropogenic $\mathrm{CO}_{2}$ by the Mediterranean Sea is mostly driven by its high alkalinity, coupled with the wintertime dense water formation events.

Numerous trap experiments have been carried out over the past decades in the Mediterranean, both in continental shelf and open-sea environments, concerning mass fluxes, budgets of particulate organic carbon and other major and minor elements (Boldrin et al., 2002; Gogou et al., 2013; Lee et al., 2009; Miquel et al., 2011; Sanchez-Vidal et al., 2005; Zúñiga et al., 2007), and variability of particle fluxes and mechanisms controlling the transfer of particulate matter to the open sea (Canals et al., 2006; Heussner et al., 2006; Martin et al., 2010; Monaco et al., 1999; Pasqual et al., 2010; Stavrakakis et al., 2000; Stavrakakis and Lykousis, 2011).

The present work focuses on the study of downward fluxes of total mass, organic carbon, carbonate, opal, and lithogenic matter, during the first four years of the experiment (February 2006 to March 2010), conducted in the deepest Mediter- ranean basin (NESTOR site), SE Ionian Sea, in the eastern Mediterranean. The time-series data set is used to identify mechanisms governing particle transport in the study area, and to explain (i) the seasonal, and (ii) the interannual variation of mass and main constituent fluxes, in relation to biogeochemical and oceanographic conditions.

\section{Study area}

\subsection{Morphological setting of the study area}

NESTOR site is located in the SE Ionian Sea, in the vicinity of SW Peloponnese (Fig. 1). The submarine morphology of the area is complicated, with steep slopes close to the Messinia/Pylos, valleys, and deep basins. The steep slope extends in short distances from the shore from 600 to $3000 \mathrm{~m}$ depth, while further offshore, from 3000 to $4000 \mathrm{~m}$ depth, the area is dominated by valleys and morphological plateaus, which incorporate the deepest basins of the Mediterranean Sea (4600 and $5264 \mathrm{~m}$ depth).

Detailed continuous sub-bottom seismic profiling revealed that the bottom sediment sequences are very thin due to the insignificant sediment inputs from the nearby continent (Trimonis and Rudenko, 1992). The steep slopes are almost free of sediments (acoustic basement) whereas valleys and plateaus are covered by undisturbed sediments (lack of slumps or massive sediment failures). The sub-bottom strata of the deep basins consist of continuous weak and parallel reflectors indicating purely pelagic sedimentation with the absence of turbidity flows (Km3NeT Collaboration, 2007).

\subsection{Hydrology and biogeochemistry}

The Ionian Sea has a complex hydrology and can be considered as a transitional area where water masses formed in the Levantine Sea, the Aegean Sea and the Adriatic Sea meet and interact with the water masses of the Western Mediterranean Sea that enter through the Sicily Strait. The typical water mass structure of the area includes: (1) the Modified Atlantic Waters (MAW) characterized by a salinity minimum and occupying the approximately upper $25-100 \mathrm{~m}$; (2) the Levantine Intermediate Waters (LIW) that occupy typically the $100-500 \mathrm{~m}$ layer and are characterized by a salinity maximum; (3) the Transitional Waters (TW) occupying the layer between 500 and $1200 \mathrm{~m}$; and (4) the Eastern Mediterranean Deep Waters (EMDW) filling the layers below $1200 \mathrm{~m}$ (Malanotte-Rizzoli et al., 1997; Nittis et al., 1993). The Eastern Mediterranean Transient (EMT) of the early 1990s further complicated this structure (Theocharis et al., 1999). The bottom waters of the Ionian Sea were occupied by the newly formed warm and saline Cretan Deep Water (CDW), which displaced the older EMDW of Adriatic origin (Klein et al., 1999). The intermediate layers were occupied by Cretan Intermediate Waters (CIW) with characteristics similar to LIW (Malanotte-Rizzoli et al., 1999). 


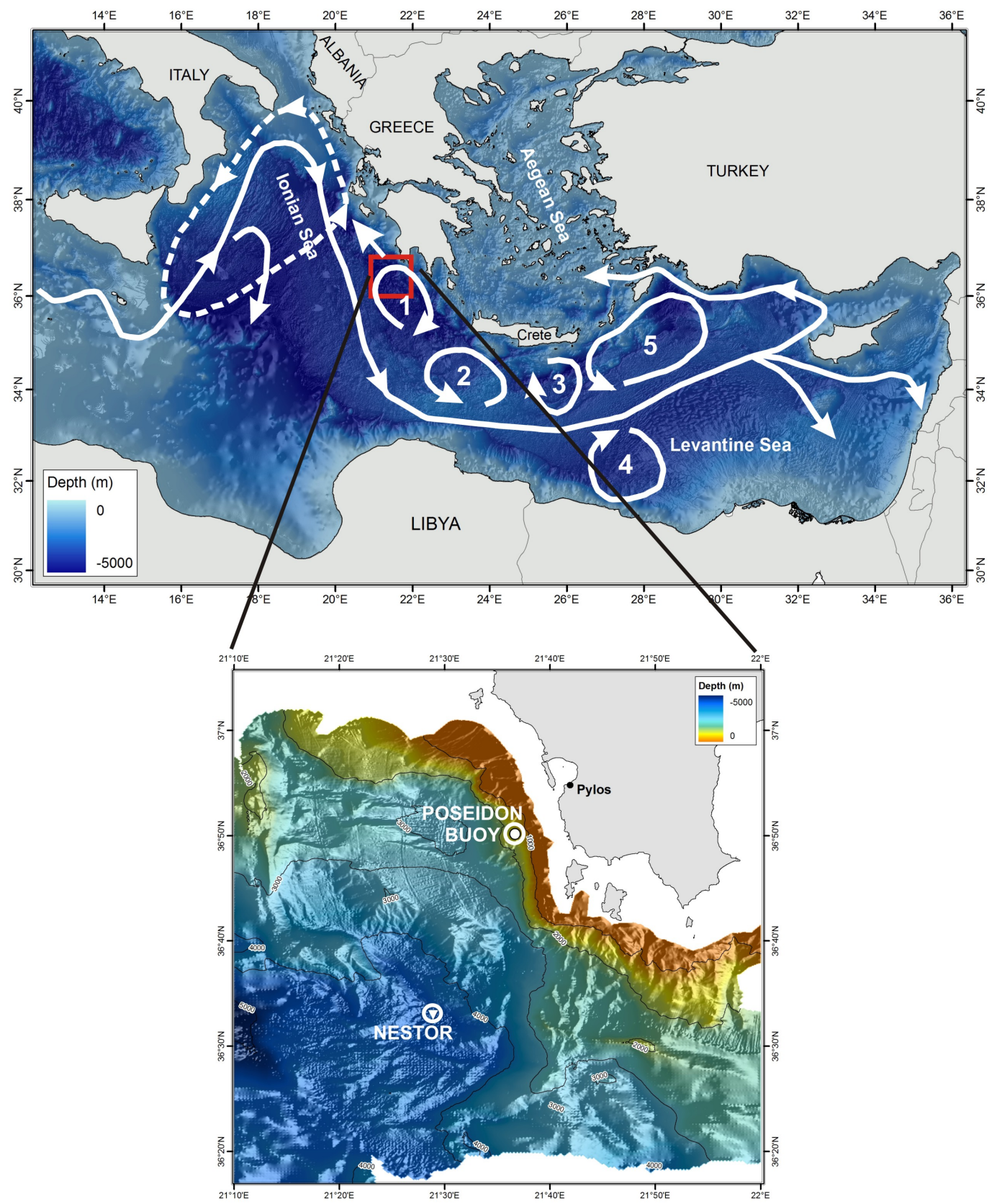

Fig. 1. Study area and location of the sampling sites in the southeast Ionian Sea (eastern Mediterranean). Schematic of the general circulation in the eastern Mediterranean in the upper $500 \mathrm{~m}$ is also presented: 1, 2, 3, 4, and 5 indicate the Pelops anticyclone, the Cretan cyclone, the Ierapetra anticyclone, the Mersha-Matruh gyre, and the Rhodes gyre, respectively. Dotted loop indicates the north Ionian gyre circulation, whenever it occurs.

New production in the Ionian Sea mostly derives from limited events in space and time, which are mainly driven by climatological factors generating mesoscale instabilities (Boldrin et al., 2002; Casotti et al., 2003; Civitarese et al., 2010; Mazzocchi et al., 2003). Oligotrophic features increase according to a north-south and west-east gradient (Bosc et al., 2004; Casotti et al., 2003; D’Ortenzio et al., 2003), in response to different water masses characteristics and cir- culation patterns. Surface chl- $\alpha$ concentrations in the eastern Ionian are generally lower than $0.2 \mathrm{mg} \mathrm{m}^{-3}$ with the occurrence of the highest values during late winter/early spring, and the lowest levels during summer (D'Ortenzio et al., 2003). A deep chlorophyll maximum is found at around 80-100 m depth (Boldrin et al., 2002; Casotti et al., 2003; Crombet et al., 2011; Karageorgis et al., 2012; Rabitti et al., 1994) exhibiting low seasonality that is related to the stable 
oligotrophic conditions of the area (Casotti et al., 2003). In general, previous studies depict that the oligotrophic Ionian Sea is dominated by a complex microbial food web (review by Siokou et al., 2010; Yokokawa et al., 2010), and dissolved organic matter (DOM) is partially bioavailable in both surface and mesopelagic and bathypelagic layers, as witnessed by the important correlation of DOC with AOU and the chemical characteristics of DOM (Meador et al., 2010).

\section{Materials and methods}

\subsection{Sampling strategy}

NESTOR mooring line was deployed at the deepest basin of the SE Ionian Sea at $4500 \mathrm{~m}$ depth $\left(36^{\circ} 32.96 \mathrm{~N}, 21^{\circ} 28.93 \mathrm{E}\right.$; Fig. 1). The mooring line was instrumented with five pairs of sediment traps (TECHNICAP PPS $3 / 3,0.125 \mathrm{~m}^{2}$ collecting area and 12 receiving cups) and current meters (AANDERAA RCM-11 and RCM-9). The five traps were set at $700,1200,2000,3200$, and $4300 \mathrm{~m}$ depth, whereas the current meters were set $3 \mathrm{~m}$ below the traps. At the deepest trap of NESTOR site $(4300 \mathrm{~m})$, the collection of settling particles started on 18 February 2006. The traps at 1200, 2000 and $3200 \mathrm{~m}$ depth commenced sampling on 3 June 2006, whilst the shallower trap at $700 \mathrm{~m}$ depth commenced sampling on 1 November 2006, thus a sampling gap is observed from October 2008 to March 2009. The collecting periods of each trap are summarized in Fig. 2a. All traps were synchronized to collect particles on a weekly (1 April 2006-31 May 2006, and 16 August 2006-7 October 2006) or bi-weekly basis. A poisoning solution of formalin (Knauer et al., 1984) was used to limit the degradation of particulate matter and to prevent the integrity of "swimmers" by hardening their cuticle. Details of mooring line preparation and preliminary sample treatment are described by Heussner et al. (1990). The water mass characteristics of the sampling area were recorded with a SeaBird CTD sensor.

During the entire sampling period, 399 samples were recovered out of the theoretical maximum of 404 (99\% success rate; Fig. 2a).

\subsection{Sample treatment and analytical procedures}

The recovered trap samples were kept in the dark at $4{ }^{\circ} \mathrm{C}$, until treated in the laboratory. Part of the supernatant was passed through a $1 \mathrm{~mm}$ nylon sieve in order to remove large organisms. Swimmers smaller than $1 \mathrm{~mm}$ were removed using fine tweezers under a light microscope. A high-precision peristaltic, microprocessor-controlled dispensing pump was used to divide each individual sample into subsamples. Subsamples for the determination of opal (biogenic silica) were filtered onto Millipore $0.45 \mu \mathrm{m}$ cellulose filters (HA), whereas subsamples for the determination of carbon and nitrogen were filtered onto Whatman glass microfiber fil-

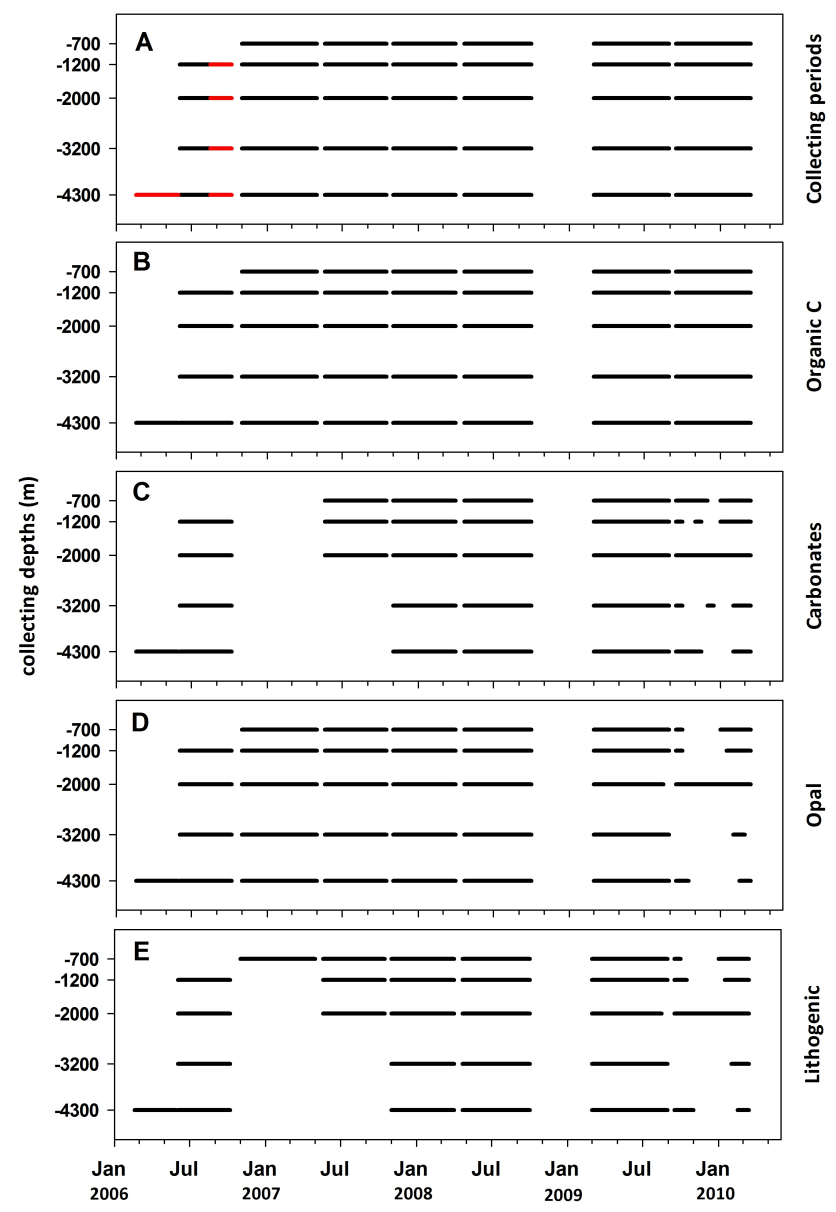

Fig. 2. (A) Duration, time and depth coverage of NESTOR trap sampling. The red lines indicate one-week sampling intervals, the black lines two-week sampling intervals; $(\mathbf{B}, \mathbf{C}, \mathbf{D}, \mathbf{E})$ time slots for organic carbon, carbonates, opal and lithogenic material, respectively, analyzed in this study.

ters $(\mathrm{GF} / \mathrm{F})$. Total mass fluxes were calculated from the dry weights of the subsamples used for opal analyses.

For the determination of organic (OC) and total (TC) carbon, subsamples of $\sim 8 \mathrm{mg}$ of sinking matter were filtered through pre-combusted $\left(450^{\circ} \mathrm{C}\right)$, pre-weighed glass-fiber filters $(\mathrm{GF} / \mathrm{F})$, which were then stored at $-20^{\circ} \mathrm{C}$ in the dark until analysis. OC and TC contents were measured with a Thermo Scientific FLASH 2000 CHNS elemental analyzer in $\mathrm{HCl}$ treated and non-treated samples, respectively (Nieuwenhuize et al., 1994). The analytical conditions are set at provider recommended parameters slightly modified according to the published works of Verardo et al. (1990), Cutter and Radford-Knoery (1991) and Nieuwenhuize et al. (1994). For the elimination of inorganic carbon, filters are firstly treated with $\mathrm{HCl} 2 \mathrm{~N}$ to prevent "explosive" sample loss during reaction with more concentrated acid in the next step, which consists of repeated additions of $\mathrm{HCl} 6 \mathrm{~N}$ with $60^{\circ} \mathrm{C}$ drying steps in between, until no further effervescence is noticed. 
From the values obtained, organic matter (OM) content was calculated by doubling the OC content $(\mathrm{OM} \%=\mathrm{OC} \% \times 2)$, carbonate content was estimated assuming all inorganic carbon (TC\%-OC \%) was $\mathrm{CaCO}_{3}$ and using the molecular mass ratio $100 / 12$ $((\mathrm{TC} \%-\mathrm{OC} \%) \times 8.33)$.

Opal concentration was determined by colorimetric reaction after extraction of silica into $2 \mathrm{M} \mathrm{Na}_{2} \mathrm{CO}_{3}$ and $2 \mathrm{~N} \mathrm{NaOH}$ solution at $85^{\circ} \mathrm{C}$ for $5 \mathrm{~h}$. According to Mortlock and Froelich (1989) opal contents were obtained by multiplying the values of $\mathrm{Si}$ concentration by a factor of 2.4 .

The lithogenic fraction (quartz, aluminosilicates, heavy minerals, etc.) was estimated by subtraction of the sum of biogenic components from 100 (lithogenic $\%=100 \%$ - (organic matter $\%+$ carbonates $\%+$ opal $\%)$ ) .

In some cases the limited amount of trapped material was insufficient for the analyses of all constituents; Fig. 2b-e shows the analyses performed for each major constituent.

\subsection{Statistical analysis}

Total mass flux data were transformed in continuous time series using 1-month step, according to Heussner et al. (2006). Missing data on the 15-day interval were computed by lineal interpolation, whilst long gaps (several months) were not corrected. The derived data set consists of mean monthly averaged total mass fluxes (mTMF), which is adequate to study the seasonal variability, although some episodic events (pulses) may have been smoothed.

The relationships of mTMF variations between different traps were studied by means of Pearson correlation coefficients; the significance level to test the correlations was $5 \%$. Principal component analysis (PCA) was used to examine the relationships of mTMF and other factors influencing their variability: (a) satellite-derived aerosol optical depth (daily AOD at $550 \mathrm{~nm}$ from MODIS; NASA GES DISC); satellitederived chlorophyll- $\alpha$ (eight-day composite from MODIS; NASA GES DISC); and (iii) salinity measured at 20, 50, $75,100,250,400$, and $500 \mathrm{~m}$ from the nearby $\left(36^{\circ} 50.15 \mathrm{~N}\right.$, $21^{\circ} 36.68$ E; Fig. 1) observational buoy of the Poseidon system (www.poseidon.hcmr.gr). Missing data and averaging was performed similarly to total mass flux data.

\section{Results}

\subsection{Hydrodynamic regime}

In the framework of the present work, the detailed analysis of the hydrographic and current meter data during 2006-2009 showed that a permanent cyclone was dominant in the deepest $\sim 2-2.5 \mathrm{~km}$, while the flow in the upper $\sim 1.5-2 \mathrm{~km}$ was variable. In February and May 2006, the upper flow was to the east and southeast, under the influence of the northern edge of the Pelops anticyclone, while it switched afterwards to the northwest in the absence of the Pelops anticyclone in our study area. In addition, CDW was detected with local maxima of temperature and salinity at $\sim 1600 \mathrm{~m}$ and at $\sim 3300 \mathrm{~m}$ depth, whereas waters of Adriatic origin existed at depths below $\sim 3600 \mathrm{~m}$ (Kontoyiannis, 2010; Kontoyiannis et al., 2012). Figure 3 shows the progressive vector diagrams derived from the current meter data at the five instrumented depths of the mooring at NESTOR. The predominant flow direction at all depths is to the north-northwest, towards directions in the range $320-340^{\circ}$. The flow at the deepest level $(4300 \mathrm{~m})$ is mostly stable in direction, i.e., along the local bathymetry towards $321^{\circ}$ on average. Fairly stable in direction is also the flow at $2000 \mathrm{~m}$ towards $\sim 340^{\circ}$ on average. Higher variability is observed in the shallower flows, i.e., at 700 and $1200 \mathrm{~m}$, which appear to be correlated to each other, i.e., nearly parallel, in the period from May 2006 until March 2008. In April 2008, the flow at $700 \mathrm{~m}$ turns to the southwest, whereas the flow at $1200 \mathrm{~m}$ turns to the west and ultimately returns back to the northeast in February 2009. Variable flow directions were also observed in the relatively short one-year record at $3200 \mathrm{~m}$. Compared to all recorded flows, the record at $3200 \mathrm{~m}$ was the only one that exhibited a flow to the southeast. This occurred in early fall of 2006, before switching to the northwest in February 2007. The speeds of the flows at all levels are extremely weak. Mean speeds are 2.9, 2.8, 1.8, 1.5 , and $2.2 \mathrm{~cm} \mathrm{~s}^{-1}$, at 700, 1200, 2000, 3200, and $4300 \mathrm{~m}$, respectively, whereas the corresponding maxima in speeds are $12,18,9,9$, and $14 \mathrm{~cm} \mathrm{~s}^{-1}$.

\subsection{Total mass flux}

Time series of total mass fluxes are illustrated in Fig. 4. Mass fluxes vary between two to three orders of magnitude at each depth. The lowest value of mass flux is recorded at $4300 \mathrm{~m}$ $\left(0.12 \mathrm{mg} \mathrm{m}^{-2} \mathrm{~d}^{-1}\right.$, December 2010$)$ and the highest at $700 \mathrm{~m}$ (484 $\mathrm{mg} \mathrm{m}^{-2} \mathrm{~d}^{-1}$, March 2010). Mean total mass fluxes measured during the experiment are generally low, confirming the oligotrophic character of the area and span over a narrow range, between $66 \mathrm{mg} \mathrm{m}^{-2} \mathrm{~d}^{-1}$ at $700 \mathrm{~m}$ and $34 \mathrm{mg} \mathrm{m}^{-2} \mathrm{~d}^{-1}$ at $3200 \mathrm{~m}$ (Fig. 4; Table 1). Since the coefficients of variation $(\mathrm{CV} \%=$ std dev/mean $\times 100)$ of mass fluxes are much higher compared to the coefficients of variation of percentages of major constituents at all depths (Table 1), the temporal evolution of fluxes of major constituents reflects the mass flux pattern. Among all traps, the upper trap shows the highest variability. However, all traps recorded the same seasonal signal with minor exceptions.

The mean monthly total mass fluxes (mTMF) of all traps vary between 5.5 and $207 \mathrm{mg} \mathrm{m}^{-2} \mathrm{~d}^{-1}$ (Fig. 5). The overall seasonal trend shows low total mass fluxes during winter, increasing in spring and peaking in May, whereas values decrease gradually during summer and autumn. The same general behavior is observed for all traps, suggesting that mean monthly total mass fluxes exhibit the same variability throughout the water column. The visual 

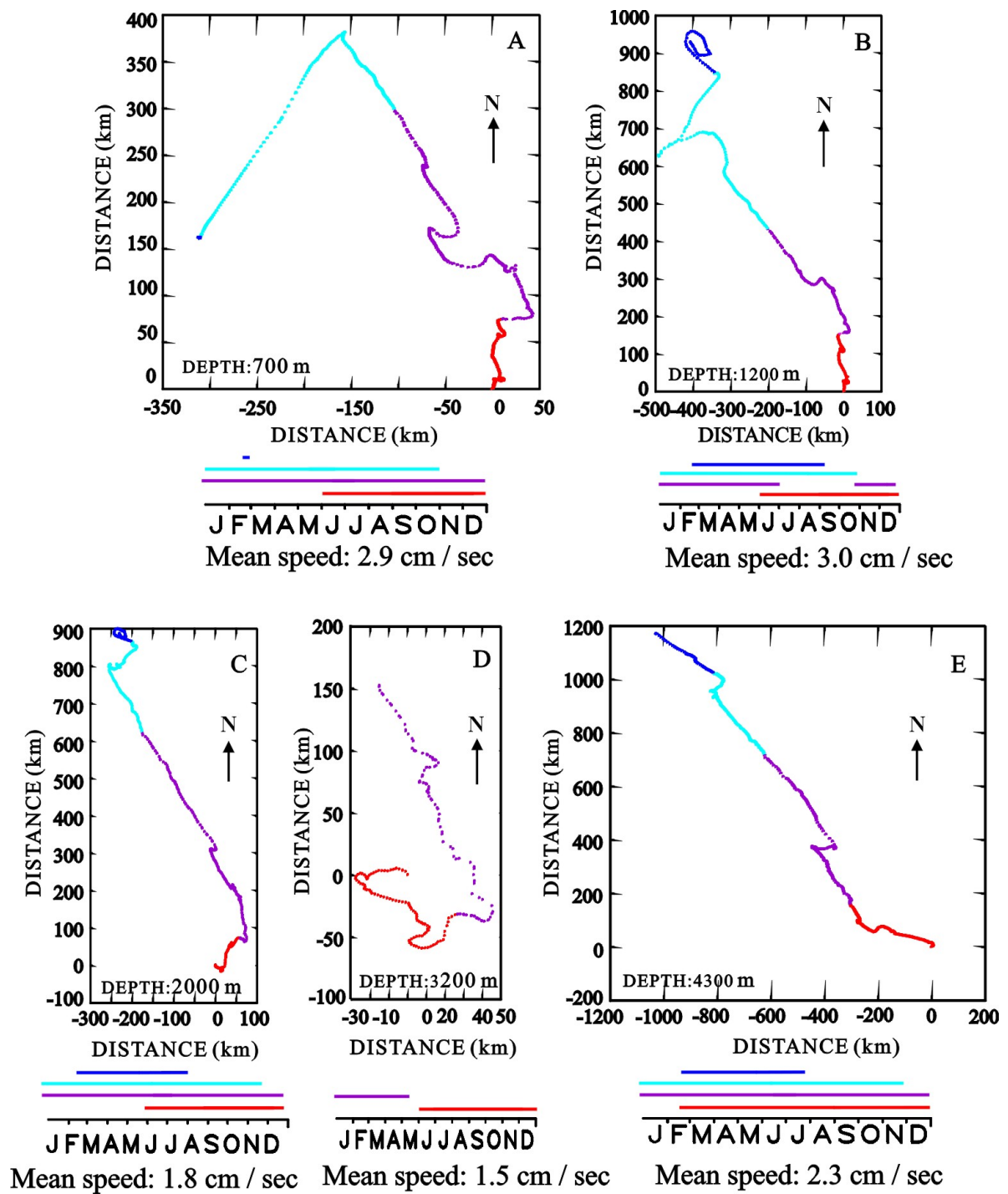

Fig. 3. Progressive vector diagrams based on unfiltered current meter data at the various depths of measurements on the mooring at NESTOR site. Corresponding colored lines below indicate the duration and time coverage of the current record for each specific year they refer to. (A) $700 \mathrm{~m}$, (B) $1200 \mathrm{~m}$, (C) $2000 \mathrm{~m}$, (D) $3200 \mathrm{~m}$, (E) $4300 \mathrm{~m}$.

examination is supported by correlation analysis; correlation coefficients were positive and significant, and varied between 0.597 and 0.984 , for $\mathrm{mTMF}_{700}: \mathrm{mTMF}_{4300}$ and $\mathrm{mTMF}_{2000}: \mathrm{mTMF}_{3200}$, respectively.

\subsection{Organic carbon}

The time series of the OC contents and fluxes of all measurements are illustrated in Fig. 6, and statistical parameters are reported in Table 1. The highest variability in terms of OC content is observed at 700 and $4300 \mathrm{~m}$, where the $\mathrm{CV} \%$ are 75 and $100 \%$, respectively, and the lowest variability at $3200 \mathrm{~m}(\mathrm{CV} \%=39)$. At $700 \mathrm{~m}$, high OC contents are observed from November 2006 to February 2007, where the total mass flux is generally low and the highest peak is observed in November (15.8\%). This November peak is also recorded at the 1200 and $2000 \mathrm{~m}$ traps, after two sampling periods. No remarkable maximum is observed at $3200 \mathrm{~m}$, while at the deepest trap the OC \% values are generally high, with maxima followed by minima. The next long period between April 2007 and May 2009 is characterized by lower and less variable OC \% contents. Another maximum of OC $\%$ appears at $700 \mathrm{~m}$ in October/November $2009(14 \%)$, followed by two other maxima at $1200 \mathrm{~m}$ in November $(11 \%)$, and at $4300 \mathrm{~m}$ in December $(9 \%)$. No peak is observed in October/November 2009 at $2000 \mathrm{~m}$ and $3200 \mathrm{~m}$. From the shallower to the deeper trap, the range of OC fluxes were 0.07 (December 2009)-13 (February/March 2010), 0.16 (February 2007)-12.29 (May 2009), 0.09 (September 2008)-11.35 (May 2009), 0.03 (January 


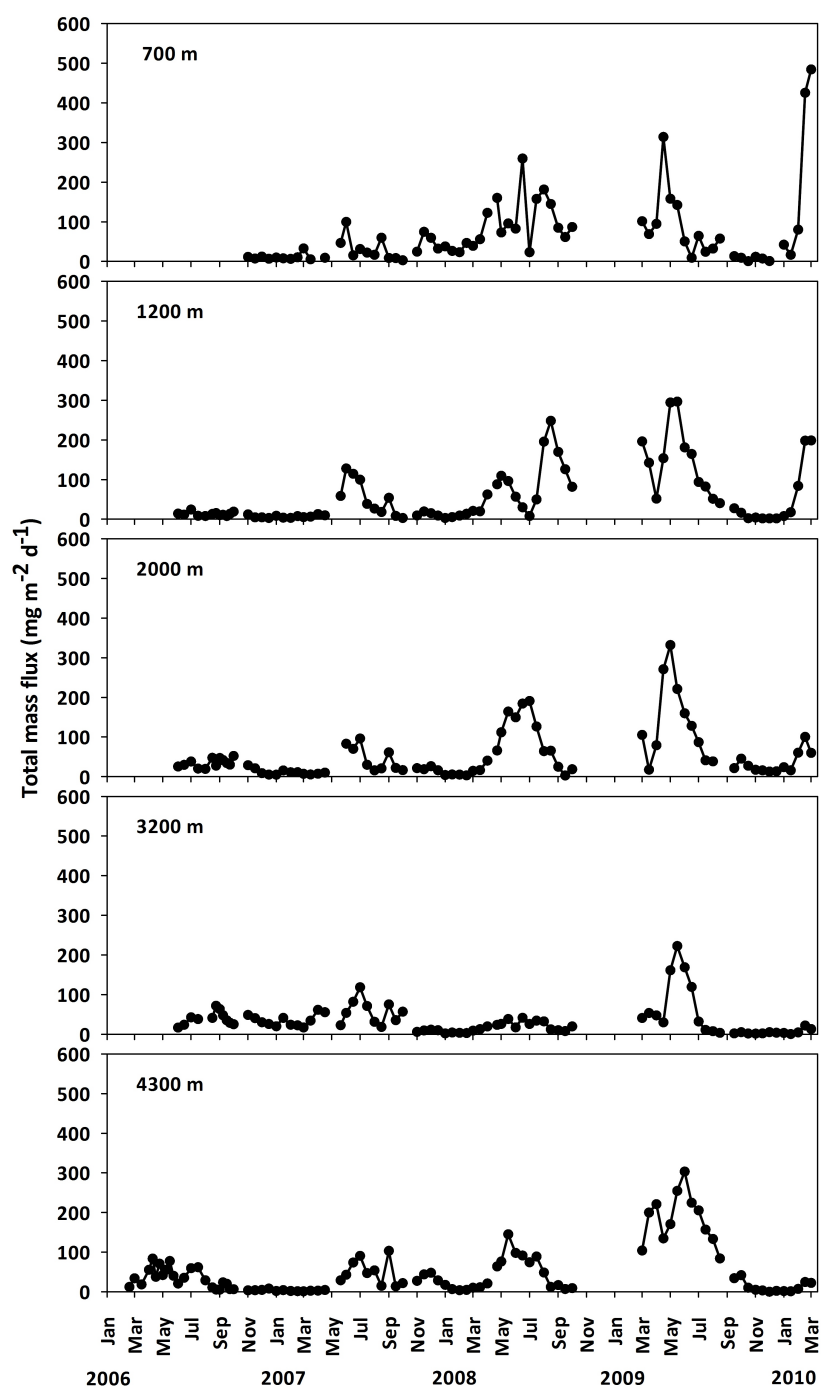

Fig. 4. Time-series plots of total mass flux $\left(\mathrm{mg} \mathrm{m}^{-2} \mathrm{~d}^{-1}\right)$ of downward settling particles collected by sediment traps during the course of the long-term experiment in NESTOR site.

2010)-7.73 (May 2009), and 0.01 (December 2009)-9.66 (May 2009) $\mathrm{mg} \mathrm{m}^{-2} \mathrm{~d}^{-1}$. It is noteworthy that (1) OC content peaks only casually coincide with OC flux peaks; and (2) the mean OC fluxes decrease from $700 \mathrm{~m}$ to $3200 \mathrm{~m}$, and increase from $3200 \mathrm{~m}$ to $4300 \mathrm{~m}$.

\subsection{Carbonates}

The time series of carbonate contents and fluxes of all measurements are illustrated in Fig. 7, and statistical parameters are reported in Table 1. Time series of carbonate contents display less variability compared to the higher variation of $\mathrm{OC}$ contents; this is confirmed by lower coefficients of variation (Table 1). Mean carbonate contents did not show any trend of increase or decrease with depth. The lower mean carbonate content $(26.5 \%)$ is recorded at $3200 \mathrm{~m}$.
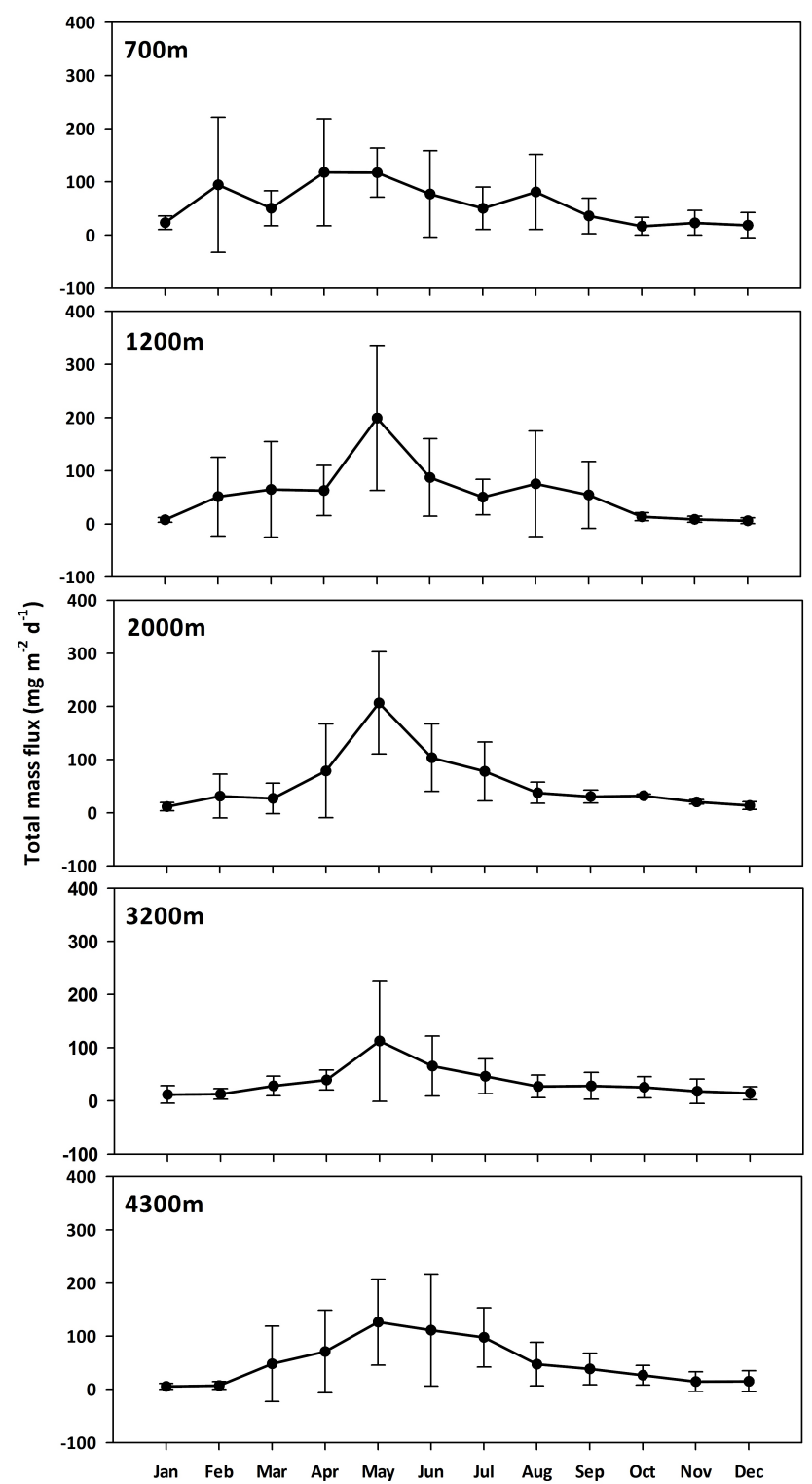

Fig. 5. Mean total mass fluxes ( \pm 1 std. dev.) of the entire four-year data set, where years were used as replicates.

Similarly to OC, the small variations in carbonate content follow the total mass flux pattern. Carbonate fluxes vary between 0.34 (December 2009) and 126.56 (March 2010) at $700 \mathrm{~m}, 0.33$ (November 2009) and 93.94 (May 2009) at $1200 \mathrm{~m}, 0.07$ (September 2008) and 82.25 (April 2009) at $2000 \mathrm{~m}, 0.27$ and 59.74 (May 2009) at $3200 \mathrm{~m}$, and 0.79 (October 2006) and $78.61 \mathrm{mg} \mathrm{m}^{-2} \mathrm{~d}^{-1}$ (May 2009) at $4300 \mathrm{~m}$. Mean carbonate fluxes decrease from $700 \mathrm{~m}$ to $3200 \mathrm{~m}$ and increase from $3200 \mathrm{~m}$ to $4300 \mathrm{~m}$ following the trend observed for the total mass flux and the OC flux. 
Table 1. Descriptive statistics of total mass and main constituent fluxes $\left(\mathrm{mg} \mathrm{m}^{-2} \mathrm{day}^{-1}\right)$, and contribution (\%) of main constituents to total mass for the different traps. Mean corresponds to time-weighted mean fluxes and flux-weighted percentages.

\begin{tabular}{|c|c|c|c|c|c|c|c|c|c|c|}
\hline \multirow{2}{*}{$\begin{array}{l}\text { Trap } \\
\text { (m) }\end{array}$} & & \multirow{2}{*}{$\begin{array}{r}\text { Total } \\
\text { mass } \\
\text { flux }\end{array}$} & \multicolumn{2}{|c|}{$\begin{array}{l}\text { Organic } \\
\text { Carbon }\end{array}$} & \multicolumn{2}{|c|}{ Carbonate } & \multicolumn{2}{|c|}{ Opal } & \multicolumn{2}{|c|}{ Lithogenic } \\
\hline & & & $\%$ & flux & $\%$ & flux & $\%$ & flux & $\%$ & flux \\
\hline \multirow[t]{5}{*}{700} & Min & 0.62 & 2.08 & 0.08 & 15.93 & 0.34 & 3.45 & 0.25 & 32.57 & 1.52 \\
\hline & Max & 484.37 & 15.79 & 12.97 & 46.96 & 126.56 & 16.98 & 50.16 & 64.00 & 282.14 \\
\hline & Mean & 65.58 & 3.89 & 2.55 & 28.29 & 22.66 & 10.15 & 7.18 & 51.70 & 33.82 \\
\hline & Std. Dev. & 92.44 & 2.92 & 2.80 & 6.51 & 25.32 & 2.913 & 9.615 & 7.76 & 59.26 \\
\hline & C.V. (\%) & 140.96 & 75.23 & 111.55 & 23.03 & 111.74 & 28.70 & 133.91 & 14.43 & 175.22 \\
\hline \multirow[t]{5}{*}{1200} & Min & 1.93 & 2.21 & 0.16 & 16.46 & 0.33 & 3.61 & 0.11 & 36.43 & 1.13 \\
\hline & $\operatorname{Max}$ & 296.70 & 10.83 & 12.29 & 46.96 & 93.94 & 22.90 & 67.93 & 69.71 & 160.94 \\
\hline & Mean & 58.07 & 3.45 & 2.00 & 29.64 & 20.96 & 12.06 & 7.46 & 51.45 & 38.09 \\
\hline & Std. Dev & 72.05 & 2.25 & 2.33 & 5.70 & 22.14 & 3.69 & 11.39 & 7.81 & 39.62 \\
\hline & C.V. (\%) & 124.07 & 65.15 & 116.50 & 19.13 & 105.63 & 30.61 & 152.68 & 15.18 & 104.02 \\
\hline \multirow[t]{5}{*}{2000} & Min & 2.88 & 1.74 & 0.09 & 20.08 & 0.07 & 6.25 & 0.38 & 40.91 & 1.45 \\
\hline & Max & 331.95 & 10.27 & 11.35 & 38.99 & 82.25 & 24.12 & 71.28 & 67.10 & 159.04 \\
\hline & Mean & 53.74 & 3.05 & 1.64 & 28.49 & 17.61 & 12.20 & 6.56 & 53.21 & 32.89 \\
\hline & Std. Dev & 63.29 & 1.52 & 1.89 & 4.29 & 16.11 & 3.23 & 11.09 & 5.93 & 35.17 \\
\hline & C.V. (\%) & 117.77 & 49.78 & 115.24 & 15.06 & 91.48 & 26.48 & 169.06 & 11.14 & 106.93 \\
\hline \multirow[t]{5}{*}{3200} & Min & 0.46 & 1.88 & 0.03 & 12.99 & 0.27 & 4.43 & 0.31 & 40.28 & 1.021 \\
\hline & Max & 222.53 & 7.87 & 7.73 & 37.21 & 59.74 & 29.31 & 50.11 & 70.32 & 97.22 \\
\hline & Mean & 34.25 & 3.20 & 1.10 & 26.41 & 8.82 & 12.98 & 5.05 & 52.00 & 18.65 \\
\hline & Std. Dev & 38.90 & 1.26 & 1.30 & 4.86 & 11.28 & 4.27 & 8.10 & 6.30 & 21.44 \\
\hline & C.V. (\%) & 113.58 & 39.46 & 118.18 & 18.39 & 127.89 & 32.90 & 160.40 & 12.12 & 112.50 \\
\hline \multirow[t]{5}{*}{4300} & Min & 0.12 & 0.06 & 0.01 & 11.56 & 0.79 & 6.06 & 0.160 & 42.20 & 2.08 \\
\hline & Max & 303.36 & 16.86 & 9.66 & 54.93 & 78.61 & 15.93 & 47.90 & 73.96 & 166.13 \\
\hline & Mean & 52.27 & 2.85 & 1.49 & 28.56 & 18.98 & 10.70 & 6.08 & 55.10 & 38.43 \\
\hline & Std. Dev & 63.09 & 2.85 & 1.77 & 6.40 & 19.05 & 2.26 & 8.33 & 6.21 & 38.02 \\
\hline & C.V. $(\%)$ & 120.71 & 99.97 & 118.79 & 22.39 & 100.37 & 21.12 & 137.01 & 11.27 & 98.93 \\
\hline
\end{tabular}

\subsection{Opal}

The time series of the opal contents and fluxes of all measurements are illustrated in Fig. 8, and statistical parameters are reported in Table 1. The variations of opal content are more pronounced than the variation of carbonate, but less than those of OC contents. Despite the fluctuation in opal content between samples, at $700 \mathrm{~m}$ the opal contents show a gradual increase from November 2006 to October 2008, and afterwards a gradual decrease until August 2008 (Fig. 8). The opal contents increase again throughout May-July 2009, where the highest values are recorded $(15.5-17 \%)$. A similar feature is observed at $1200 \mathrm{~m}$, but here the major peak of May 2009 is more pronounced (23\%). This trend is less evident at $2000 \mathrm{~m}$, and the spring (May-June) maximum is slightly higher $(21.5-24 \%)$. At $3200 \mathrm{~m}$, four main peaks are recorded: (1) September 2006 (16.5\%); (2) January 2008 (19\%); (3) May 2009 (22\%); and (4) February 2010 (29\%). At $4300 \mathrm{~m}$, the opal content displays the lowest variability. Mean opal contents are very similar at 1200, 2000 and
$3200 \mathrm{~m}(12-13 \%)$, and slightly lower at 700 and $4300 \mathrm{~m}$ (10.2 and $10.7 \%$, respectively).

The opal fluxes vary between 0.3 (November 2006) and 50 (March 2010), 0.1 (December 2006) and 68 (May 2009), 0.4 (September 2008) and 71 (May 2009), 0.4 (February 2008) and 50 (May 2009), 0.2 (March 2007) and $48 \mathrm{mg} \mathrm{m}^{-2} \mathrm{~d}^{-1}$ (June 2009), for 700, 1200, 2000, 3200, and $4300 \mathrm{~m}$, respectively. Inversely to OC fluxes, opal fluxes do not exhibit considerable decrease with depth.

\subsection{Lithogenic fraction}

The time series of the lithogenic contents and fluxes of all measurements are illustrated in Fig. 9, while statistical parameters are reported in Table 1. Lithogenic constituents represent the major proportion of the total mass flux, with contents varying between 33 and $70 \%$. Mean contents of the lithogenic fraction remain almost constant at each collecting depth, with a slight trend to increase towards the deeper traps. It is noteworthy that the CVs \% of the lithogenic component are the lowest among the CVs of all other major constituents. 


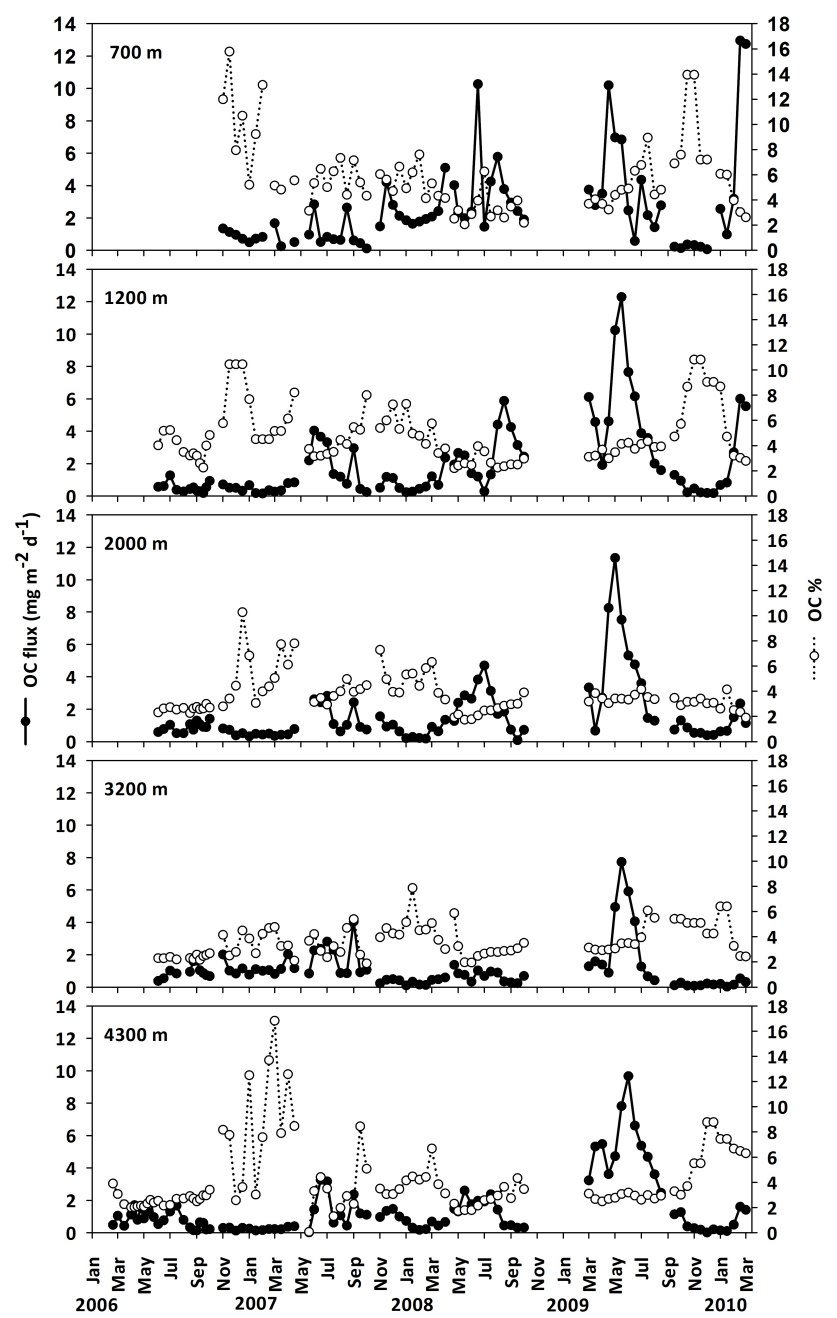

Fig. 6. Time-series plots of organic carbon content (\%) and fluxes $\left(\mathrm{mg} \mathrm{m}^{-2} \mathrm{~d}^{-1}\right)$ of downward settling particles collected by sediment traps during the course of the long-term experiment in NESTOR site.

Mean lithogenic fluxes are from top to bottom: 34, 38, 33,19 , and $38 \mathrm{mg} \mathrm{m}^{-2} \mathrm{~d}^{-1}$. The lithogenic flux patterns follow largely the total mass flux patterns, resulting from the low CVs of lithogenic percentages and the high variations of total mass fluxes. Lithogenic fluxes vary from 2 (October 2007) to 282 (March 2010), 1 (October 2007) to 160 (August 2008), 2 (February 2008) to 159 (May 2009), 1 (January 2008) to 97 (May 2009), and 2 (February 2008) to 166 (June 2009) $\mathrm{mg} \mathrm{m}^{-2} \mathrm{~d}^{-1}$ for $700,1200,2000,3200$, and $4300 \mathrm{~m}$, respectively.

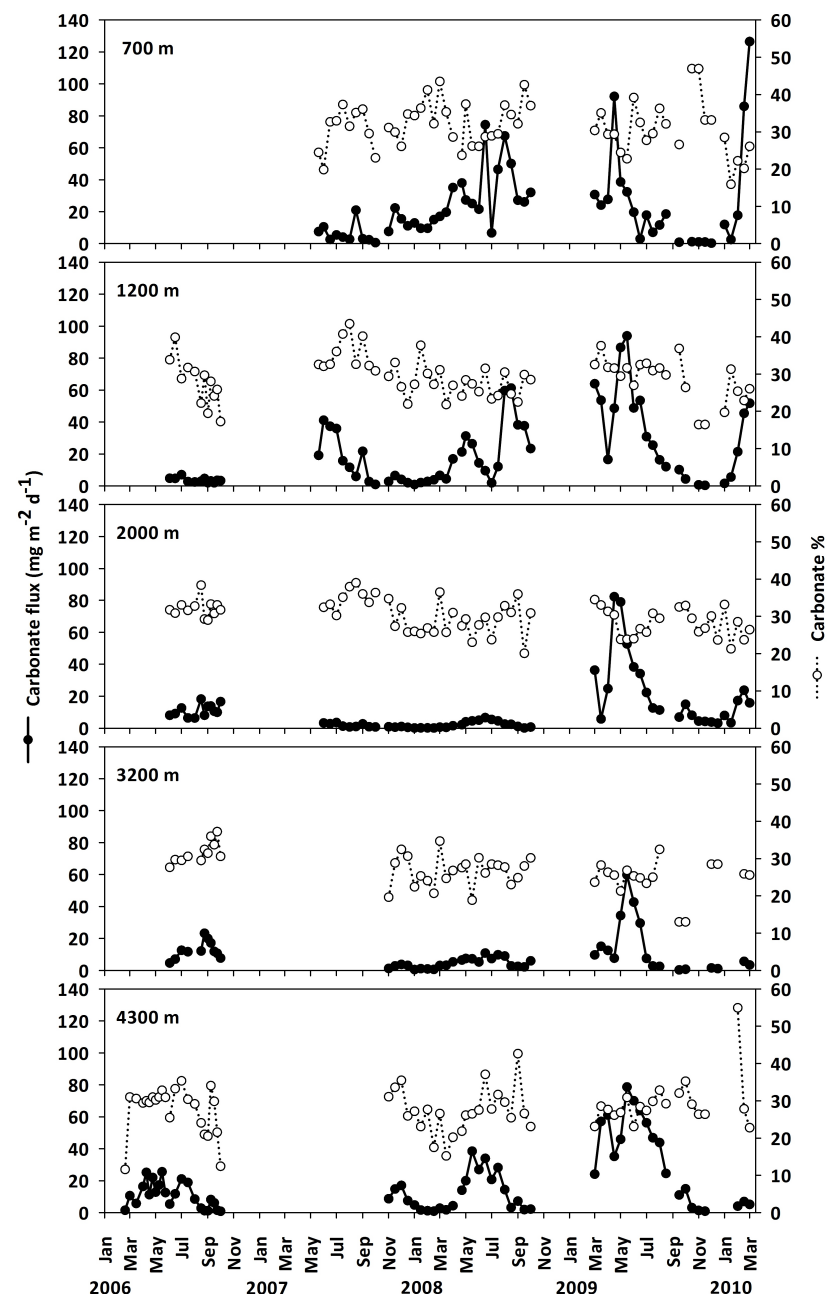

Fig. 7. Time-series plots of carbonate content (\%) and fluxes $\left(\mathrm{mg} \mathrm{m}^{-2} \mathrm{~d}^{-1}\right)$ of downward settling particles collected by sediment traps during the course of the long-term experiment in NESTOR site.

\section{Discussion}

\subsection{Vertical fluxes in the deep layers of NESTOR site}

The vertical distribution of mean total mass fluxes during the entire four-year experiment shows a general decrease with depth, from $700 \mathrm{~m}$ downward to $3200 \mathrm{~m}$, whereas at the $4300 \mathrm{~m}$ relatively increased fluxes are observed (Fig. 4; Table 1). Karageorgis et al. (2008) studied the seasonal particle dynamics in the NESTOR area by means of transmissometry and showed that the broader NESTOR area is characterized by very low beam attenuation (beam $c_{p}$ ) values, decreasing over depth. Only extremely faint intermediate and benthic nepheloid layers (INL and BNL, respectively) detaching from the shelf break and slope moving horizontally along isopycnals were recorded, thus feeding the seabed with very small amounts of particulate matter. In both cases, INLs and 


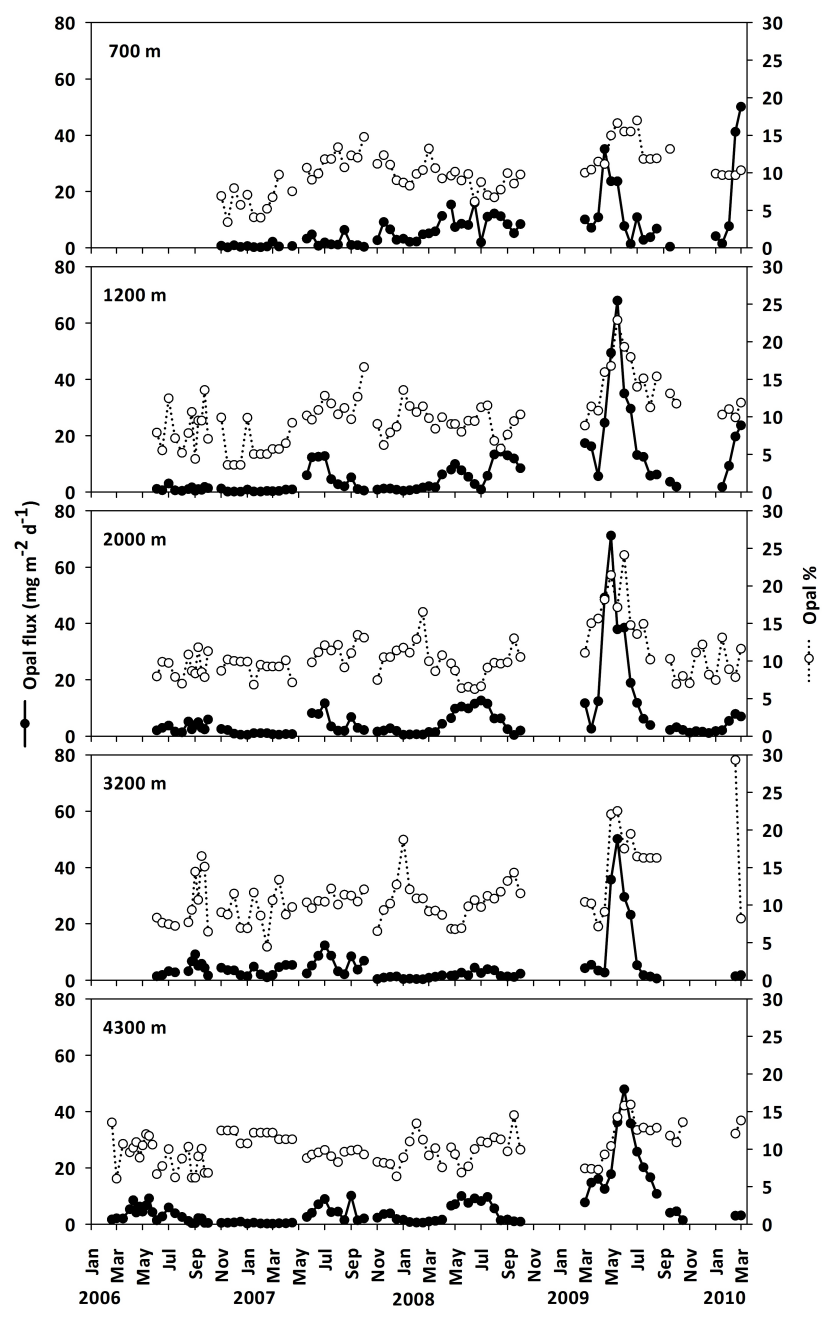

Fig. 8. Time-series plots of opal content (\%) and fluxes $\left(\mathrm{mg} \mathrm{m}^{-2} \mathrm{~d}^{-1}\right)$ of downward settling particles collected by sediment traps during the course of the long-term experiment in NESTOR site.

BNLs were extremely faint and corresponded to very small differences in beam attenuation (Karageorgis, 2007). The variability of mass fluxes between the 3200 and $4300 \mathrm{~m}$ traps may be attributed to the presence of water masses with different turbidity. Indeed, CDW which occupies waters between 1600 and $3300 \mathrm{~m}$ is a very transparent, almost particle-free water mass (Karageorgis et al., 2008). The unique character of CDW, in combination with the lowest measured mean flow speed $\left(1.5 \mathrm{~cm} \mathrm{~s}^{-1}\right)$ appearing at the same depth may explain the relatively lower mass fluxes recorded at the $3200 \mathrm{~m}$ trap. In contrast, relatively higher mass fluxes (represented mainly by the lithogenic fraction) observed at the deeper trap may be attributed to the presence of EMDW, well-known for its higher turbidity (e.g., De Lazzari et al., 1999; Kontoyiannis and Lykousis, 2011).

Measured mean total mass fluxes are comparable to those reported for other sectors of the Mediterranean Sea. In

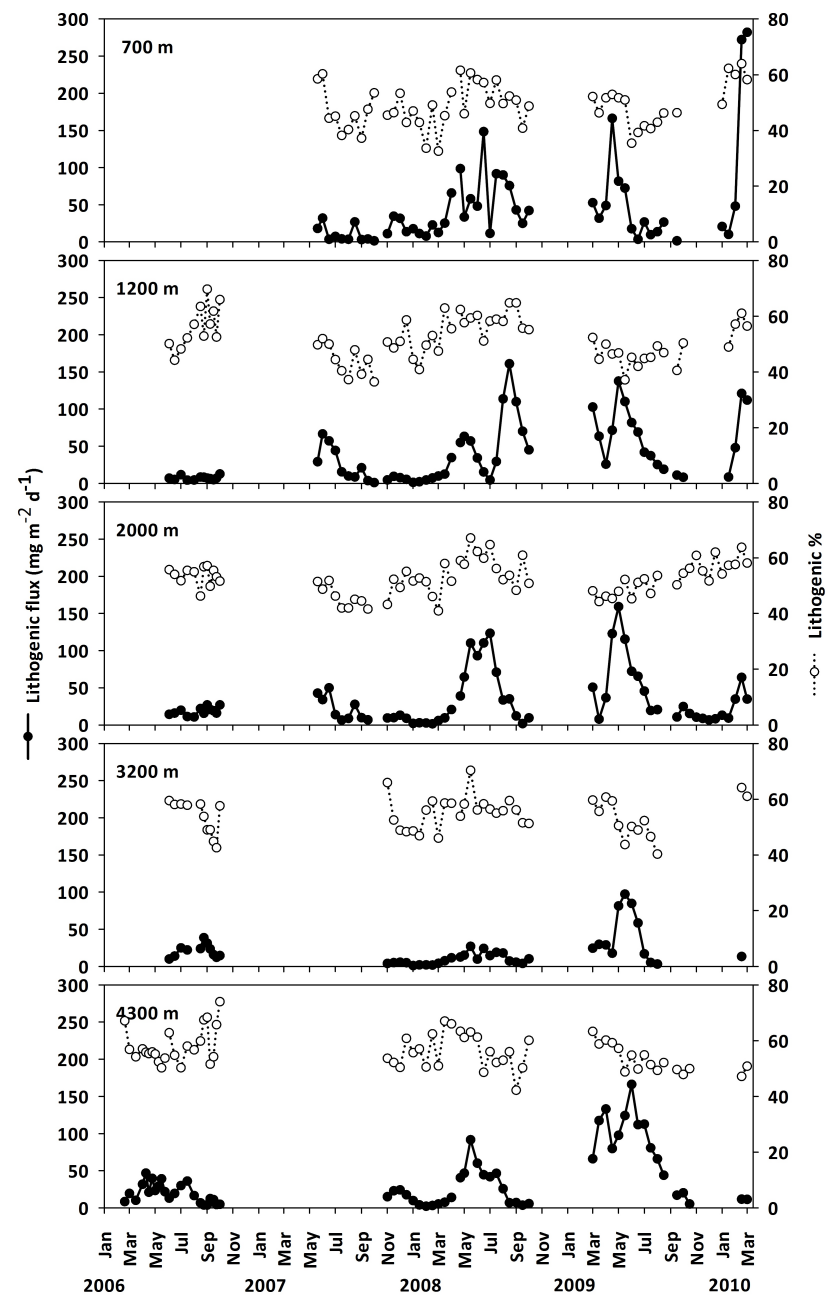

Fig. 9. Time-series plots of lithogenic fraction content $(\%)$ and fluxes $\left(\mathrm{mg} \mathrm{m}^{-2} \mathrm{~d}^{-1}\right)$ of downward settling particles collected by sediment traps during the course of the long-term experiment in NESTOR site.

the central part of the Algero-Balearic Basin, Zúñiga et al. (2007) measured in four sediment traps $(250,845,1440$, and $1820 \mathrm{~m}$ ) mean total mass fluxes $<400 \mathrm{mg} \mathrm{m}^{-2} \mathrm{~d}^{-1}$. In the eastern Alboran Sea, Sanchez-Vidal et al. (2004) estimated at several depths $(510-2230 \mathrm{~m})$ mean total mass fluxes substantially higher, in the range of $\sim 20$ to $2400 \mathrm{mg} \mathrm{m}^{-2} \mathrm{~d}^{-1}$. In the DYFAMED site situated in the Ligurian Sea, Miquel et al. (2011) reported mean total mass flux from minimum values $\sim 3 \mathrm{mg} \mathrm{m}^{-2} \mathrm{~d}^{-1}$ to a maximum of $1228 \mathrm{mg} \mathrm{m}^{-2} \mathrm{~d}^{-1}$ at $200 \mathrm{~m}$, and 2 to $893 \mathrm{mg} \mathrm{m}^{-2} \mathrm{~d}^{-1}$ at $1000 \mathrm{~m}$. Boldrin et al. (2002) reported mean fluxes of 106 and $196 \mathrm{mg} \mathrm{m}^{-2} \mathrm{~d}^{-1}$ at 150 and $1050 \mathrm{~m}$, respectively, in the southern Adriatic Sea and 36 and $17 \mathrm{mg} \mathrm{m}^{-2} \mathrm{~d}^{-1}$ at 150 and $2250 \mathrm{~m}$, respectively, in the northern Ionian Sea.

In the eastern Mediterranean, Stavrakakis et al. (2000) measured mean total mass fluxes in the Cretan Sea of 187 and $550 \mathrm{mg} \mathrm{m}^{-2} \mathrm{~d}^{-1}$ at 200 and $1515 \mathrm{~m}$, respectively, whereas 
Kerhervé et al. (1999), measured in the Antikythira Strait 96 and $299 \mathrm{mg} \mathrm{m}^{-2} \mathrm{~d}^{-1}$ at 880 and $1345 \mathrm{~m}$ depth, respectively.

Amongst available data given above, the mean mass flux of $52 \mathrm{mg} \mathrm{m}^{-2} \mathrm{~d}^{-1}$ recorded at the deepest trap in our study site lies within the lowest values observed in the Mediterranean and should be associated with low sedimentation rates at the seabed. Assuming that all particles collected by the trap reach the seabed, the sedimentation rate is estimated at $1-1.45 \mathrm{~cm} \mathrm{kyr}^{-1}$. This value is in good agreement with sedimentation rates reported earlier for the area, in the order of $0.7-1.8 \mathrm{~cm} \mathrm{kyr}^{-1}$ (Trimonis and Rudenko, 1992) or 0.86$1.89 \mathrm{~cm} \mathrm{kyr}^{-1}$ (Polimeris et al., 2009). Additionally, sediment cores collected close to the location of NESTOR site reveal sedimentation rates of $1.6-1.7 \mathrm{~cm} \mathrm{kyr}^{-1}$ (Km3NeT Collaboration, 2007), which is also in good agreement with those estimated from sediment trap measurements in our study.

A general behavior observed for the total mass flux, as well as all measured constituent fluxes, is the appearance of maxima and minima almost simultaneously at the five traps, though at varying intensities (Figs. 4-9). Such a pattern outlines the predominance of vertical transport over lateral inputs of particulate matter in the area, notwithstanding the fact that water masses move much faster laterally than mean particle sinking rates (thousands of $\mathrm{m} \mathrm{d}^{-1}$ vs. $10-100 \mathrm{~m} \mathrm{~d}^{-1}$; Buesseler et al., 2007).

\subsection{Seasonal variability}

The temporal distribution of total mass flux exhibited strong seasonal patterns, with higher fluxes recorded mainly in late winter/early spring followed by a second and more pronounced flux maximum period in late spring/summer, and significantly lower fluxes in autumn/winter (Fig. 4). This oscillation in total mass flux was observed throughout the fouryear experiment, although a marked interannual variability in export intensities is observed.

Primary productivity in the Ionian Sea, as in most oligotrophic sites of the subtropical Mediterranean Sea, displays high seasonal variability with maximum rates observed during the winter/spring convective mixing period (Bosc et al., 2004; D'Ortenzio and Ribera d'Alcala, 2009). In our time series, this feature was observed to coincide with relative increases in organic carbon and opal contents and fluxes at all depths during late winter/early spring (Figs. 6 and 8) that could be attributed to the development of siliceous blooms in the euphotic zone. After that, nanophytoplankton species (e.g. coccolithophorids) probably gained more importance as primary producers, as it is witnessed by the increase in the carbonate contents during the less productive periods (Fig. 7). In respect to this finding, Ignatiades et al. (2009) showed that coccolithophores are the main planktonic calcifiers in the eastern Mediterranean and a major contributor to biogenic particle export production on a seasonal basis (Malinverno et al., 2009; Triantaphyllou et al., 2004).
All biogenic fluxes (OC, carbonate, opal; Figs. 6-8) exhibited a second, more pronounced maximum in late spring/early summer, indicating the existence of a triggering process that enhances the export of all biogenic constituents. The blooming period which mainly occurs in late winter/early spring could be ascribed to the upwelling of nutrient-rich waters and/or to direct nutrient input from the atmosphere (D'Ortenzio and Ribera d'Alcala, 2009; Guerzoni et al., 1999; Markaki et al., 2010). Furthermore, time series of salinity obtained from the neighboring observational Poseidon buoy shows the upwelling of the high salinity LIW and/or Cretan Intermediate Water at $\sim 350 \mathrm{~m}$ in May 2008 , 2009 and 2010 (Fig. 10). The upwelling process may be related to the observed seasonal variability of the intensity and position of the Pelops anticyclonic gyre (Larnicol et al., 2002). The latter authors, using satellite altimetry, demonstrate that the Pelops gyre was repeatedly observed to weaken or disappear in late spring and early to mid-summer and reappear in fall. The weakening or even the absence of the Pelops gyre at the study site could permit the upward movement of the intermediate masses favoring the observed upwelling.

During late spring/early summer, the lithogenic fluxes were also considerably high (65 and $85 \mathrm{mg} \mathrm{m}^{-2} \mathrm{~d}^{-1}$, in 2008 and 2009 , respectively, at the $700 \mathrm{~m}$ trap), thus indicating enhanced lithogenic inputs (Fig. 9). The aeolian transport and episodic dust events is the prevailing process transferring lithogenic material in the Ionian Sea (Gkikas et al., 2013, Guerzoni et al., 1999, Kalivitis et al., 2011), an area characterized by the absence of important riverine inputs. The aerosol optical depth (AOD) is a measure of radiation extinction due to aerosol scattering and absorption (Giovanni online manual) and may be used as a satellite-derived proxy for potential dust events. An increase of AOD over NESTOR area, which is concomitant to the increase of lithogenic content and flux during e.g. April 2000 and April 2009, supports the notion of enhanced lithogenic inputs from the atmosphere (Fig. 11).

During winter and spring the Mediterranean region is affected by two upper air jet streams: the polar front jet stream, originally located over Europe, and the subtropical jet stream, which is typically located over northern Africa. The combined effects of these westerly jets in winter and spring support the propagation of extratropical cyclones towards east and southeast, resulting in dust plume intrusion in the Mediterranean (Özsoy et al., 2001). Moulin et al. (1998) show a clear seasonal signal of the African dust transport, which begins in spring over the eastern Mediterranean Basin, maximizes in summer over the central and western basins and dramatically decreases during autumn and winter. Dust deposition plays an important role in fueling the surface waters of the eastern Mediterranean Sea with nutrients, thus having important implications on pelagic productivity and functioning of the food web (Guerzoni et al., 1999; Herut et al., 2002; Kouvarakis et al., 2001; Krom et al., 1991, 2002; 


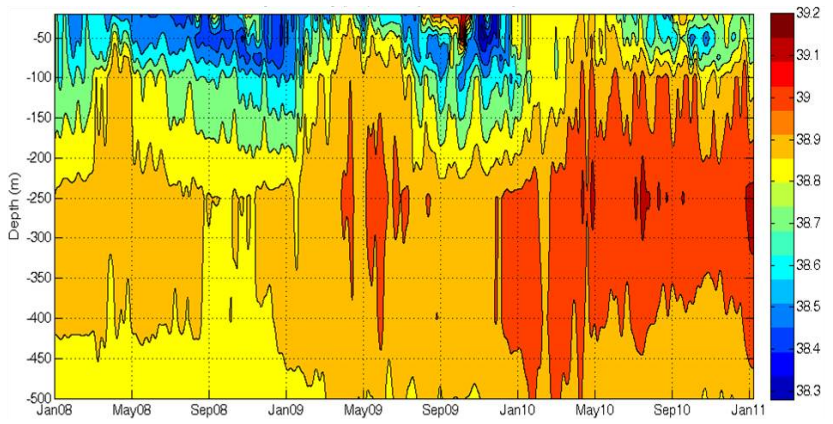

Fig. 10. Time-depth contour plot of the salinity evolution in the upper $500 \mathrm{~m}$ as recorded by the Poseidon Buoy (shown in Fig. 1) at NESTOR site.

Loye-Pilot et al., 1990; Markaki et al., 2003; Ridame and Guieu, 2002; Thingstad and Rassoulzadegan, 1995).

It should be noted, however, that dust input does not always cause analogous changes in the content and flux of the lithogenic fraction (Fig. 11). This is probably due to the different atmospheric conditions prevailing during the dust loading events in the atmosphere, i.e., wind speed, precipitation. Indeed, strong wind events force deeper convection in a cyclonic structure such as the one reported for the northern Ionian Sea since 1998 (Manca et al., 2003) and produce a larger vertical transport of nutrients in the photic layer, allowing an enhanced plankton growth. The above description is also confirmed by Boldrin et al. (2002) and Patara et al. (2009), who present data of sediment trap experiments conducted in the Ionian Sea.

The small peak of total mass flux at the $700 \mathrm{~m}$ trap in $\mathrm{Au}$ gust 2007 is associated with high atmospheric ash fallout originating in massive forest fires, which affected the western and southern Peloponnese (Theodosi et al., 2013). In addition, Stavrakakis and Lykousis (2011) identified ample charcoal ash by scanning electron microscopy. Considering that many fires may be related to human activities, it should be noted that sediment traps can also record anthropogenic impacts.

Distinct peaks of total mass flux observed at the $700 \mathrm{~m}$ trap are often observed at deeper traps, but with a considerable time offset (Fig. 4). During April 2009, a major peak in total mass flux was recorded at the $700 \mathrm{~m}$ trap, which was also observed at all depths with a delay of $\sim 15$ days between traps. Finally, the peak was recorded at the $4300 \mathrm{~m}$ trap in June (Fig. 4). Assuming a total transport time of 45 days, the particle settling velocity would be $60-80 \mathrm{~m} \mathrm{~d}^{-1}$. This value is lower than previous estimates of $200 \mathrm{~m} \mathrm{~d}^{-1}$ of Patara et al. (2009), who deployed sediment traps at 500 and $2800 \mathrm{~m}$ between 1999 and 2001, SW of the NESTOR site.

We have shown that the seasonal variability of mass fluxes is influenced by aeolian inputs, primary productivity and upwelling. PCA was performed in order to identify possible interrelationships between those control factors and mean

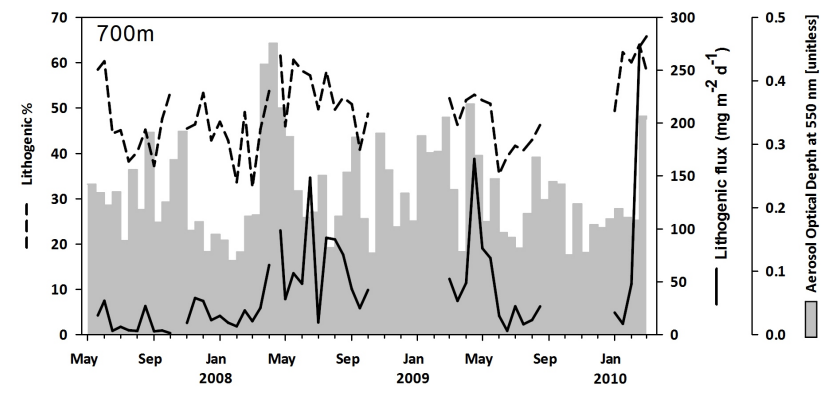

Fig. 11. Time-series plot of lithogenic content and flux, and aerosol optical depth at $550 \mathrm{~nm}$. Analyses of aerosol optical depth used in this plot were produced with the Giovanni online data system, developed and maintained by the NASA GES DISC.

monthly total mass fluxes at all depths. We use as proxies for dust inputs, primary production, and upwelling, the AOD time series, the satellite-derived total chl- $\alpha$, and salinity time series at $50 \mathrm{~m}$ depth, respectively. A Varimax rotated matrix (Table 3) shows that a simple model of 2 factors explains $83.7 \%$ of the total data variability. Factor 1 accounts for $55.9 \%$ of the total variance and contains positive loadings for all mTMF and AOD, whereas chl- $\alpha$ is negatively loaded (Table 3). Factor 1 portrays the lithogenic constituent of the total mass flux, which is positively related to atmospheric inputs/dust events. Relatively low loading for mTMF at $700 \mathrm{~m}$ denotes that other processes contribute to the total mass flux at the shallowest observation depth. Factor 2 accounts for $27.8 \%$ of the total variance and relates salinity, mTMF at $700 \mathrm{~m}$, chl- $\alpha$, and AOD. We suggest that F2 represents the biogenic components of the total mass flux, controlled mainly by the upwelling of high-salinity and nutrientrich deep waters, which enhance primary productivity at upper water layers. Relatively low loading of chl- $\alpha$ may be attributed to poor performance of regional algorithms used to compute chlorophyll concentrations from remote sensing reflectance. In the oligotrophic waters of the eastern Mediterranean, the presence of absorbing aerosols (desert dust) results in inaccurate atmospheric corrections (Bosc et al., 2004 and references therein), whereas CDOM variability alters the optical properties of surface waters. Interestingly, AOD is positively loaded in the "biogenic" factor, suggesting that atmospheric aerosols, apart from lithogenic components, may also transfer nutrients to the sea, thus enhancing primary productivity (Guerzoni et al., 1999; Markaki et al., 2010). Overall, PCA findings confirm visual observations and provide insight into studying relationships between various parameters.

\subsection{Interannual variability}

A considerable interannual variability in vertical distributions is observed in the total mass flux maxima at various depths, despite some similarities in the seasonal patterns 
(Fig. 4). The main feature of the mass flux variability (Table 2 and Fig. 4) was the gradual increase of winter mass flux almost at all depths, followed by an evident analogous increase (with some exceptions) in spring and summer mass flux. Such an interannual change in flux patterns could be explained by the reinforcement of processes which produce and/or transfer particulate matter in the area.

A plausible reason for the increase of fluxes from 2006 to 2010 could be related to the general circulation patterns at the study site, which exhibit strong interannual variability. During mid-late 1990s the large-scale anticyclonic circulation observed during the 1980s and early 1990s was confined to the southern part and replaced by a cyclonic circulation in the northern Ionian (Borzelli et al., 2009; Gačić et al., 2011; Larnicol et al., 2002). In the years following 2006, the salinity and nutrient changes in the south Adriatic suggest that the Ionian circulation was changed back into anticyclonic (Civitarese et al., 2010). This latter circulation regime causes the upwelling of the nutricline in the periphery of the anticyclonic gyre and the weakening or even the absence of the Pelops gyre. The NESTOR site is obviously found at the edge of this anticyclone as revealed from the recurrent shoaling of the isohalines recorded in the nearby observational buoy of the Poseidon system (Fig. 10). Furthermore, the remarkable enhancement of the fluxes from 2008 onwards seems to be directly dependent on the intensity of the intrusion in the upper layer of high salinity intermediate waters of Levantine/Cretan origin. The upward movement of these intermediate waters could favor upwelling of nutrients and enrichment of the upper layer, thus triggering surface productivity and the enhancement of downward particle fluxes. In respect to this hypothesis, the increased contribution of all biogenic (OC, carbonate, opal) constituents in late spring/summer of 2008 and 2009, suggests an effective nutrient fueling of the upper layer created by the dynamic conditions prevailing in the vicinity of NESTOR site. The large-scale processes and changes affecting the Ionian Sea is considered to play a crucial role in the production of phytoplanktonic biomass (D'Ortenzio et al., 2003) and may control the biogeochemical functioning of the Ionian Sea.

\subsection{Organic carbon export}

Depth profiles of sinking particle fluxes in the ocean are characterized by rapid attenuation of OC fluxes in the mesopelagic zone, between the base of the euphotic zone $(\sim 100-200 \mathrm{~m})$ and roughly $1000 \mathrm{~m}$, below which $<10 \%$ of the export flux is detectable (Buesseler, 1998). Explanations commonly offered for this behavior include the existence of different reactivity classes of organic matter that attenuate sequentially with depth, a more extensive heterotrophic processing of organic matter in the biologically active upper water column, and the "ballast" hypothesis (Lee et al., 2009 and references therein). According to the latter, the fluxes of ballast minerals (calcium carbonate, opal, and lithogenic matter) and the organic carbon fluxes are closely correlated in the mesopelagic and bathypelagic zones of the ocean, leading to a hypothesis that organic carbon export is determined by the presence of ballast minerals within settling aggregates (Armstrong et al., 2002; Francois et al., 2002). Additionally, previous studies (De La Rocha et al., 2008; Klaas and Archer; 2002; Passow, 2004) proposed the "glue hypothesis", according to which the incorporation of inorganic minerals to OCrich material (e.g., marine snow) might increase their sinking rates. Several previous studies (Engel et al., 2004; Gogou et al., 2010; Passow et al., 2001; Verdugo et al., 2004), have shown that organic-rich "gels" are abundant and important components of aggregates throughout the water column of the ocean.

In our experiment, potential relationships between $\mathrm{OC}$ and ballast minerals fluxes are examined in Fig. 12a, b and c. Ballast mineral fluxes all exhibit very good correlations with OC fluxes $\left(R^{2}=0.86\right.$ for all correlations of OC vs. ballast minerals). The oligotrophic character of the study site, with low OC contents for particles reaching higher depths, pinpoints to a mechanism where organic matter is related through "glue" or "ballasting" processes to different types of available inorganic matrices (e.g., carbonate, opal and lithogenics) during carbonate- or silicious-species blooming and during episodic dust input events. Furthermore, the OC \% content increases towards periods characterized by lower particulate export rates, with a power function giving the best fit for organic carbon versus mass flux (Fig. 12d). Given that much of the mass flux is not represented by OC, but is due to ballast minerals, these results suggest that the $\mathrm{OC} /$ ballast ratio is higher for more slowly settling material, as has been reported before by other authors (Heussner et al., 2006; Lee et al., 2009). This can also be seen in more temporal detail in measurements of OC, carbonate, opal and lithogenic fluxes, showing higher relative contributions of organic matter and reduced contributions of mineral ballast in the upper trap during low mass flux periods, while the opposite trend is apparent for high flux periods (Figs. 6-9).

In order to describe the change in OC flux with depth, sediment trap measurements and empirical relationships have been used before (e.g., Buesseler and Boyd, 2009 and references therein; Francois et al., 2002; Honda et al., 1997; Martin et al., 1987; Suess, 1980). The most commonly used is the Martin curve (Martin et al., 1987), expressed as

$F_{z}=F_{100}(z / 100)^{-b}$

where $F_{z}$ is the OC flux at depth $z(\mathrm{~m}), F_{100}$ is the OC flux at $100 \mathrm{~m}$, and $b$ is a unitless parameter determining the degree of flux attenuation with depth $\left(F_{100}=50.4 \mathrm{mg} \mathrm{C} \mathrm{m}^{-2} \mathrm{~d}^{-1}\right.$, and $b=0.858$ in the original equation). The exponent $b$ is not a constant factor (Francois et al., 2002; Lutz et al., 2002) and it is controlled by several biological and physical processes, i.e., zooplankton swimming and excretion at depth (Bishop et al., 1986; Bishop, 1989), variability of the mixed 
Table 2. A summary of seasonally compiled fluxes of total mass $\left(\mathrm{mg} \mathrm{m}^{-2} \mathrm{~d}^{-1}\right)$ for the period 2006-2010. The definitions of the seasons are as follows: Winter: January-March; Spring: April-June; Summer: July-September; and Autumn: October-December.

\begin{tabular}{|c|c|c|c|c|c|c|}
\hline & & $700 \mathrm{~m}$ & $1200 \mathrm{~m}$ & $2000 \mathrm{~m}$ & $3200 \mathrm{~m}$ & $4300 \mathrm{~m}$ \\
\hline \multirow{4}{*}{2006} & Winter & & & & & \\
\hline & Spring & & & & & 48.32 \\
\hline & Summer & & 12.87 & 31.82 & 44.86 & 31.29 \\
\hline & Autumn & 9.31 & 7.57 & 19.49 & 34.90 & 5.34 \\
\hline \multirow{4}{*}{2007} & Winter & 11.98 & 5.95 & 9.12 & 26.76 & 2.35 \\
\hline & Spring & 24.85 & 65.19 & 42.01 & 56.42 & 30.44 \\
\hline & Summer & 19.26 & 40.68 & 40.61 & 57.97 & 53.51 \\
\hline & Autumn & 40.45 & 11.33 & 19.74 & 18.66 & 33.96 \\
\hline \multirow{4}{*}{2008} & Winter & 38.22 & 12.18 & 8.12 & 5.81 & 9.16 \\
\hline & Spring & 129.99 & 73.28 & 123.57 & 28.09 & 84.76 \\
\hline & Summer & 109.88 & 133.33 & 79.40 & 20.44 & 41.51 \\
\hline & Autumn & & & & & \\
\hline \multirow{4}{*}{2009} & Winter & & & & & \\
\hline & Spring & 130.33 & 191.20 & 199.45 & 124.87 & 217.65 \\
\hline & Summer & 29.81 & 59.27 & 46.77 & 11.15 & 122.75 \\
\hline & Autumn & 2.32 & 4.84 & 21.89 & 3.25 & 4.29 \\
\hline 2010 & Winter & 201.31 & 97.59 & 50.24 & 8.15 & 11.02 \\
\hline
\end{tabular}

Table 3. Factor loadings after Varimax rotation.

\begin{tabular}{lrr}
\hline Variable & $\begin{array}{r}\mathrm{F} 1 \\
(55.9 \%)\end{array}$ & $\begin{array}{r}\mathrm{F} 2 \\
(27.8 \%)\end{array}$ \\
\hline mTMF 700 m & 0.580 & 0.690 \\
mTMF 1200 m & 0.852 & 0.399 \\
mTMF 2000 m & 0.897 & 0.303 \\
mTMF 3200 m & 0.924 & 0.218 \\
mTMF 4300 m & 0.931 & 0.170 \\
AOD & 0.550 & 0.499 \\
chl $a$ & -0.746 & 0.538 \\
salinity & 0.172 & 0.935 \\
\hline
\end{tabular}

layer depth (Fischer et al., 1996), and plankton community structure (Boyd and Newton, 1995).

In order to estimate carbon export ratios in the oligotrophic Ionian Sea, we used primary production values from the literature, organic carbon fluxes obtained by the four NESTOR sediment traps (the $4300 \mathrm{~m}$ trap was excluded, to avoid even minor influence of BNL at that depth) and the $f$ ratio defined as the proportion of primary production exported from the euphotic zone (Eppley and Peterson, 1979).

Primary production values are derived either from satellite imagery (Antoine and Morel, 1995; Bosc et al., 2004; Bricaud et al., 2002; Colella et al., 2004) or from direct measurements (Bianchi et al., 1999; Moutin and Raimbault, 2002). For the Eastern Mediterranean Basin, Bricaud et al. (2002) reported primary production rates between 375 and $501 \mathrm{mg} \mathrm{C} \mathrm{m}^{-2} \mathrm{~d}^{-1}$, whereas for the North Io-
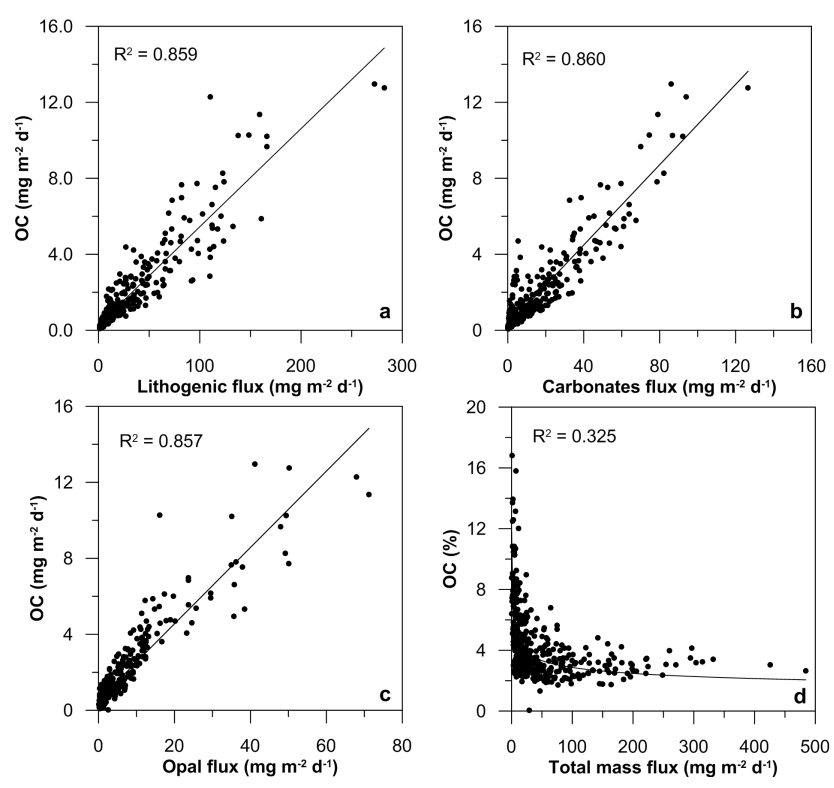

Fig. 12. Organic carbon flux vs. (a) lithogenic flux; (b) carbonate flux; (c) opal flux; and (d) organic carbon content vs. total mass flux.

nian, Bosc et al. (2004) reported values between 318 and $356 \mathrm{mg} \mathrm{C} \mathrm{m}^{-2} \mathrm{~d}^{-1}$. Colella et al. (2004) using satellite data estimated a mean primary production of $241 \mathrm{mg} \mathrm{C} \mathrm{m}^{-2} \mathrm{~d}^{-1}$ for the Ionian Sea, which is slightly lower than the $285 \mathrm{mg} \mathrm{C} \mathrm{m}^{-2} \mathrm{~d}^{-1}$ given by Antoine and Morel (1995) for the entire Ionian Basin. Recently, Taillandier et al. (2012), 
Table 4. Comparison of organic carbon fluxes (in $\mathrm{mg} \mathrm{C} \mathrm{m}^{-2} \mathrm{~d}^{-1}$ ) measured by sediment traps and in brackets the corresponding export ratios $(\%)$ at various depths with the organic carbon fluxes and export ratios obtained by empirical equations.

\begin{tabular}{llllll}
\hline $\begin{array}{l}\text { Depth } \\
(\mathrm{m})\end{array}$ & $\begin{array}{l}\text { Organic } \\
\text { carbon flux }^{\mathrm{a}}\end{array}$ & Martin $^{\mathrm{b}}$ & Betzer $^{\mathrm{c}}$ & Suess $^{\mathrm{d}}$ & Pace $^{\mathrm{e}}$ \\
\hline & & $241 \mathrm{PP}$ & & & \\
100 & & $36.15(15 \mathrm{FR})$ & $49.14(20.39 \mathrm{FR})$ & $92.98(38.58 \mathrm{FR})$ & $28.90(11.99 \mathrm{FR})$ \\
700 & $2.58(1.07)$ & $2.58(1.87)$ & $14.48(6.01)$ & $14.28(5.93)$ & $6.93(2.87)$ \\
1200 & $2.18(0.90)$ & $1.45(1.05)$ & $10.32(4.28)$ & $8.38(3.48)$ & $4.66(1.94)$ \\
2000 & $1.74(0.72)$ & $0.84(0.35)$ & $7.49(3.11)$ & $5.04(2.09)$ & $3.21(1.33)$ \\
3200 & $1.12(0.46)$ & $0.51(0.21)$ & $5.57(2.31)$ & $3.16(1.31)$ & $2.27(0.94)$ \\
4300 & $1.63(0.68)$ & $0.37(0.15)$ & $4.63(1.92)$ & $2.35(0.98)$ & $1.83(0.76)$ \\
$4500 \mathrm{~B}^{\mathrm{g}}$ & & $0.35(0.15)$ & $4.50(1.87)$ & $2.25(0.93)$ & $1.77(0.73)$ \\
\hline
\end{tabular}

PP: Primary production (Colella et al., 2004)

FR: $f$ ratio (organic carbon flux/primary production $\%$ at $100 \mathrm{~m}$ )

a: Measured by sediment traps

b. Estimated by modified Martin's equation, $b=1.07$ (see text)

c: $F_{z}=0.388 \times z^{-0.628} \times P P^{1.41}$ (Betzer et al., 1984)

d: $F_{z}=P P \times(0.0238 \times z+0.212)^{-1}$ (Suess, 1980)

e: $F_{z}=P P \times 3.523 \times z^{-0.734}$ (Pace et al., 1987)

g: Bottom

reported $323 \mathrm{mg} \mathrm{C} \mathrm{m}^{-2} \mathrm{~d}^{-1}$ (SeaWiFS for the period 19982001) total primary production for the eastern Mediterranean Sea. Estimates of primary production measured by ${ }^{14} \mathrm{C}$ in the north Ionian were $169 \mathrm{mg} \mathrm{C} \mathrm{m}^{-2} \mathrm{~d}^{-1}$ (Bianchi et al., 1999), and between 255 and $325 \mathrm{~m} \mathrm{C} \mathrm{m}^{-2} \mathrm{~d}^{-1}$ during May-June 1996 (Moutin and Raimbault, 2002). For the calculations, the daily annual mean of $241 \mathrm{mg} \mathrm{C} \mathrm{m}^{-2} \mathrm{~d}^{-1}$ (Colella et al., 2004) is used because (1) this value refers to the Ionian Basin rather than the entire eastern Mediterranean; and (2) primary production estimates based on direct measurements in the Ionian Sea are intermittent. Using the primary production of $241 \mathrm{mg} \mathrm{C} \mathrm{m}^{-2} \mathrm{~d}^{-1}$ for the Ionian Sea (Colella et al., 2004) and the $f$ ratio of 0.15 given by Laws et al. (2000) for oligotrophic areas, an organic carbon flux of $36 \mathrm{mg} \mathrm{C} \mathrm{m}^{-2} \mathrm{~d}^{-1}$ at $100 \mathrm{~m}$ depth was calculated. The latter value and OC flux data as calculated in our sediment trap experiment were used to obtain the exponent $b$ of Martin's equation, providing $b=1.07$. Francois et al. (2002) reported $b$ values ranging between 2.01 and 0.59 , from numerous sites distributed oceanwide. Sanchez-Vidal et al. (2005) determined the exponent $b$ for data of the Alboran Sea and gave a value of 0.753 , while Zúñiga et al. (2007) for the Algero-Balearic Basin provide a $b$ Value of 0.918 . Heussner at al. (2006) calculated a higher value $(b=0.687)$ on the continental slope of the Gulf of Lions, related probably to the occurrence of resuspension processes from the continental shelf. Recently, Gogou et al. (2013) reported the carbon export power functions in three open sites of the southern European seas ( $b$ values of 0.92 , 1.07, and 0.36 for the western, eastern Mediterranean, and the Black Sea, respectively). Exponent $b$ for the open eastern Mediterranean appears to be relatively higher compared to those reported for the western Mediterranean, indicating probably greater organic carbon flux attenuation in the upper several hundred meters of the water column in the eastern basin (Buesseler and Boyd, 2009).

In Table 4, we compared export ratios at the collecting depths and at $100 \mathrm{~m}$ with the estimations obtained using the empirical models of Betzer et al. (1984), Suess (1980), and Pace et al. (1987). The organic carbon fluxes, and thus the export ratios, were always underestimated, with the higher deviation to be observed at $100 \mathrm{~m}$ depth, decreasing towards deeper waters. The export ratios estimated from the sediment trap data are also low compared to those reported for other oceanic areas (Honda, 2003). The worldwide estimation of the fraction of OC transported to the global ocean at depths $>1500 \mathrm{~m}$ ranges from 0.10 to $8.8 \%$ (average $1.1 \%$ ) of surface primary production, and from 0.28 to $30 \%$ (average $5.7 \%$ ) of export from the base of the euphotic zone (Lutz et al., 2002). Our values below the $1500 \mathrm{~m}$ depth are between 0.46 and $0.72 \%$, i.e., lower than the global average of $1.1 \%$, whereas the available organic carbon to export below the euphotic zone ( $8.6 \%$ of photosynthetically produced organic carbon) is higher than the global average of $5.5 \%$ (Lutz et al., 2002). Zúñiga et al. (2007) give export ratios in the Algero-Balearic Basin (western Mediterranean) higher (2.42-0.70\%), but comparable to our values. In the Alboran Sea (SW Mediterranean), Sanchez-Vidal et al. (2005) report much higher values (5.74-1.79\%). Moutin and Raimbault (2002), using free drifting sediment traps in the Ionian Sea, reported export ratios at $100 \mathrm{~m}$ between 2.8 and $3.4 \%$ (MayJune 1996), while Lepore et al. (2009) reported an export ratio of $6.1 \%$ in the south Aegean (Cretan Sea), possibly during early spring bloom; those values are lower, but comparable to our estimates. Boldrin et al. (2002) provided for the north Ionian export ratios of $3.9 \%$ and $0.8 \%$, at $150 \mathrm{~m}$ and $2250 \mathrm{~m}$ depth, respectively, values relatively similar to our values. The export ratio of $\sim 8 \%$ at $100 \mathrm{~m}$ (Table 4 ), reveals 
that $\sim 92 \%$ of the organic carbon produced by photosynthetic processes has been respired back to inorganic carbon or released as dissolved organic carbon in the first $100 \mathrm{~m}$ of the water column. Finally, only a small portion of primary production $(0.46 \%)$ reach at $3200 \mathrm{~m}$, corresponding to a mean annual carbon export of $1.12 \mathrm{~g} \mathrm{C} \mathrm{m}^{-2} \mathrm{yr}^{-1}$ at this depth.

Acknowledgements. This work was supported by the HERMIONE FP7-DG-Environment, Km3NeT/FP6-DG-Environment and MEDECOS (Marin-ERA, FP6) EU Projects and the Greek General Secretariat of Research and Technology. Analyses and visualizations used in this paper were produced with the Giovanni online data system, developed and maintained by the NASA GES DISC. We gratefully acknowledge the officers and crew of the R/V Aegaeo for their invaluable assistance during the numerous mooring deployments and recoveries, sometimes under rough weather conditions. We are also thankful to P. Renieris and A. Morfis for technical assistance. The authors are grateful to two anonymous reviewers for their valuable comments which significantly contributed to improve the manuscript.

Edited by: R. Danovaro

\section{References}

Aït-Ameur, N. and Goyet, C.: Distribution and transport of natural and anthropogenic $\mathrm{CO}_{2}$ in the Gulf of Cádiz, Deep-Sea Res. Pt. II, 53, 1329-1343, 2006.

Álvarez, M., Pérez, F., Shoosmith, D. R., and Bryden, H. L.: Unaccounted role of Mediterranean Water in the drawdown of anthropogenic carbon, J. Geophys. Res., 110, C09S03, doi:10.1029/2004jc002633, 2005.

Antoine, D., Morel, A., and Andre, J. M.: Algal pigment distribution and primary production in the eastern Mediterranean as derived from coastal zone color scanner observations, J. Geophys. Res., 100, 16193-116209, 1995.

Armstrong, R. A., Lee, C., Hedges, J. I., Honjo, S., and Wakeham, S. G.: A new, mechanistic model for organic carbon fluxes in the ocean based on the quantitative association of POC with ballast minerals, Deep-Sea Res. Pt. II, 49, 219-236, 2002.

Betzer, P. R., Showers, W. J., Laws, E. A., Winn, C. D., DiTullio, G. R., and Kroopnick, P. M.: Primary productivity and particle fluxes on a transect of the equator at $153^{\circ} \mathrm{W}$ in the Pacific Ocean, Deep-Sea Res. Pt. I, 31, 1-11, 1984.

Bianchi, F., Boldrin, A., Civitarese, G., Del Negro, P., Giordani, P., Malaguti, A., Socal, G., Rabitti, S., and Turchetto, M. M.: Biogenic particulate matter and primary productivity in the Southern Adriatic and Northern Ionian seas. 4th MTP-Workshop MATER, Perpignan (France), Abstracts Volume, Les Presses Littéraires, Saint-Esteve, 120-121, 1999.

Bishop, J. K. B.: Regional extremes in particulate matter composition and flux: effects on the chemistry of the ocean interior, in: Productivity of the Ocean: Present and Past, edited by: Berger, W. H., Smetacek, V. S., Wefer, G., John Wiley \& Sons Limited, 117-137, 1989.

Bishop, J. K. B., Stepien, J. C., and Wiebe, P. H.: Particulate matter distributions, chemistry and flux in the panama basin: response to environment forcing, Progr. Oceanogr., 17, 1-59, 1986.
Boldrin, A., Miserocchi, S., Rabitti, S., Turchetto, M. M., Balboni, V., and Socal, G.: Particulate matter in the southern Adriatic and Ionian Sea: Characterisation and downward fluxes, J. Mar. Syst., 33-34, 389-410, 2002.

Borzelli, G. L. E., Gačič, M., Cardin, V., and Civitarese, G.: Eastern Mediterranean transient and reversal of the Ionian Sea circulation, Geophys. Res. Lett., 36, L15108, doi:10.1029/2009g1039261, 2009.

Bosc, E., Bricaud, A., and Antoine, D.: Seasonal and interannual variability in algal biomass and primary production in the Mediterranean Sea, as derived from 4 years of SeaWiFS observations, Global Biogeochem. Cy., 18, GB1005, doi:10.1029/2003GB002034, 2004.

Boyd, P. and Newton, P.: Evidence of the potential influence of planktonic community structure on the interannual variability of particulate organic carbon flux, Deep-Sea Res. Pt. I, 42, 619-639, 1995.

Bricaud, A., Bosc, E., and Antoine, D.: Algal biomass and sea surface temperature in the Mediterranean Basin Intercomparison of data from various satellite sensors, and implications for primary production estimates, Remote Sens. Environ., 81, 163-178, 2002.

Broecker W. S. and Peng T. H.:. Tracers in the Sea. Lamont-Doherty Geological Observatory, Palisades, NY, 1982.

Buesseler, K. O.: The decoupling of production and particulate export in the surface ocean, Global Biogeochem. Cy., 12, 297-310, 1998.

Buesseler, K. O. and Boyd, P. W.: Shedding light on processes that control particle export and flux attenuation in the twilight zone of the open ocean, Limnol. Oceanogr., 54, 1210-1232, 2009.

Buesseler, K. O., Lamborg, C. H., Boyd, P. W., Lam, P. J., Trull, T. W., Bidigare, R. R., Bishop, J. K. B., Casciotti, K. L., Dehairs, F., Elskens, M., Honda, M., Karl, D. M., Siegel, D. A., Silver, M. W., Steinberg, D. K., Valdes, J., Van Mooy, B., and Wilson, S.: Revisiting carbon flux through the ocean's twilight zone, Science, 316, 567-570, 2007.

Canals, M., Puig, P., De Madron, X. D., Heussner, S., Palanques, A., and Fabres, J.: Flushing submarine canyons, Nature, 444, 354357, 2006.

Casotti, R., Landolfi, A., Brunet, C., D’Ortenzio, F., Mangoni, O., Ribera d'Alcala, M., and Denis, M.: Composition and dynamics of the phytoplankton of the Ionian Sea (eastern Mediterranean), J. Geophys. Res., 108, 8116, doi:10.1029/2002JC001541, 2003.

Civitarese, G., Gačić, M., Lipizer, M., and Eusebi Borzelli, G. L.: On the impact of the Bimodal Oscillating System (BiOS) on the biogeochemistry and biology of the Adriatic and Ionian Seas (Eastern Mediterranean), Biogeosciences, 7, 3987-3997, doi:10.5194/bg-7-3987-2010, 2010.

Colella, S., D’Ortenzio, F., Marullo, S., Santoleri, R., Ragni, M., and Ribera d'Alcala, M.: Primary production variability in the Mediterranean Sea from SeaWiFS data, Proc. SPIE 5233, P. Soc. Photo.-Opt. Ins., 371-393, doi:10.1117/12.516791, 2004.

Conte, M. H., Ralph, N., and Ross, E. H.: Seasonal and interannual variability in deep ocean particle fluxes at the Oceanic Flux Program (OFP)/Bermuda Atlantic Time Series (BATS) site in the western Sargasso Sea near Bermuda, Deep-Sea Res. Pt. II, 48, 1471-1505, 2001.

Crombet, Y., Leblanc, K., Quéguiner, B., Moutin, T., Rimmelin, P., Ras, J., Claustre, H., Leblond, N., Oriol, L., and Pujo-Pay, 
M.: Deep silicon maxima in the stratified oligotrophic Mediterranean Sea, Biogeosciences, 8, 459-475, doi:10.5194/bg-8-4592011, 2011.

Cutter, G. A. and Radford-Knoery, J. Determination of carbon, nitrogen, sulfur and inorganic sulfur species in marine particles, in: Marine particles: analysis and characterization, edited by: Hurd, D. C. and Spencer, D. W., American Geophysical Union, Geophys. Monogr. Ser., 63, 57-63, 1991.

De Lazzari, A., Boldrin, A., Rabitti, S., and Turchetto, M. M.: Variability and downward fluxes of particulate matter in the Otranto Strait area, J. Mar. Syst., 20, 399-413, 1999.

De La Rocha, C. L., Nowald, N., and Passow, U.: Interactions between diatom aggregates, minerals, particulate organic carbon, and dissolved organic matter: Further implications for the ballast hypothesis, Global Biogeochem. Cy., 22, GB4005, doi:10.1029/2007GB003156, 2008.

D'Ortenzio, F. and Ribera d'Alcalà, M.: On the trophic regimes of the Mediterranean Sea: a satellite analysis, Biogeosciences, 6, 139-148, doi:10.5194/bg-6-139-2009, 2009.

D’Ortenzio, F., Ragni, M., Marullo, S., and Ribera d'Alcala, M.: Did biological activity in the Ionian Sea change after the Eastern Mediterranean Transient? Results from the analysis of remote sensing observations, J. Geophys. Res., 108, 8113, doi:10.1029/2002JC001556, 2003.

Engel, A., Thoms, S., Riebesell, U., Rochelle-Newall, E., Zondervan, I.: Polysaccharide aggregation as a potential sink of marine dissolved organic carbon, Nature, 428, 929-932, 2004.

Eppley, R. W. and Peterson, B. J.: Particulate organic matter flux and planktonic new production in the deep ocean, Nature, 282, 677-680, doi:10.1038/282677a0, 1979.

Fabres, J., Tesi, T., Velez, J., Batista, F., Lee, C., Calafat, A., Heussner, S., Palanques, A., and Miserocchi, S.: Seasonal and eventcontrolled export of organic matter from the shelf towards the Gulf of Lions continental slope, Cont. Shelf Res., 28, 19711983, 2008.

Fischer, G., Donner, B., Ratmeyer, V., Davenport, R., and Wefer, G.: Distinct year-to-year particle flux variations off Cape Blanc during 1988-1991: Relation to $\delta^{18} \mathrm{O}$-deduced sea-surface temperatures and trade winds, J. Mar. Res., 54, 73-98, 1996.

Francois, R., Honjo, S., Krishfield, R., and Manganini, S.: Factors controlling the flux of organic carbon to the bathypelagic zone of the ocean, Global Biogeochem. Cy., 16, 34-31, 2002.

Gačić, M., Civitarese, G., Eusebi Borzelli, G. L., Kovačević, V., Poulain, P.-M., Theocharis, A., Menna, M., Catucci, A., and Zarokanellos, N. On the relationship between the decadal oscillations of the northern Ionian Sea and the salinity distributions in the eastern Mediterranean, J. Geophys. Res., 116, C12002,doi:10.1029/2011JC007280, 2011.

Gkikas, A., Hatzianastassiou, N., Mihalopoulos, N., Katsoulis, V., Kazadzis, S., Pey, J., Querol, X., and Torres, O.: The regime of desert dust episodes in the Mediterranean based on contemporary satellite observations and ground measurements, Atmos. Chem. Phys. Discuss., 13, 16247-16299, doi:10.5194/acpd-13-162472013, 2013.

Gogou, A. and Repeta, D. J.: Particulate-dissolved transformations as a sink for semi-labile dissolved organic matter: Chemical characterization of high molecular weight dissolved and surfaceactive organic matter in seawater and in diatom cultures, Mar. Chem., 121, 215-223, 2010.
Gogou, A., Sanchez-Vidal, A., Durrieu de Madron, X., Stavrakakis, S., Calafat, A., Stabholz, M., Psarra, S., Canals, M., Heussner, S., Stavrakaki, I., and Papathanassiou, V.: Carbon Flux to the Deep in three open sites of the Southern European Seas (SES), J. Mar. Syst., in press, doi:10.1016/j.jmarsys.2013.05.013, 2013.

Guerzoni, S., Chester, R., Dulac, F., Herut, B., Loÿe-Pilot, M. D., Measures, C., Migon, C., Molinaroli, E., Moulin, C., Rossini, P., Saydam, C., Soudine, A., and Ziveri, P.: The role of atmospheric deposition in the biogeochemistry of the Mediterranean Sea, Progr. Oceanogr., 44, 147-190, 1999.

Haake, B., Ittekkot, V., Rixen, T., Ramaswamy, V., Nair, R. R., and Curry, W. B.: Seasonality and interannual variability of particle fluxes to the deep Arabian sea, Deep-Sea Res. Pt. I, 40, 1323 1344, 1993.

Herut, B., Collier, R., and Krom, M. D.: The role of dust in supplying nitrogen and phosphorus to the Southeast Mediterranean, Limnol. Oceanogr., 47, 870-878, 2002.

Heussner, S., Ratti, C., and Carbonne, J.: The PPS 3 time-series sediment trap and the trap sample processing techniques used during the ECOMARGE experiment, Cont. Shelf Res., 10, $943-$ 958, 1990.

Heussner, S., Durrieu de Madron, X., Calafat, A., Canals, M., Carbonne, J., Delsaut, N., and Saragoni, G.: Spatial and temporal variability of downward particle fluxes on a continental slope: Lessons from an 8-yr experiment in the Gulf of Lions (NW Mediterranean), Mar. Geol., 234, 63-92, 2006.

Honda, M. C.: Biological Pump in Northwestern North Pacific, J. Oceanogr., 59, 671-684, 2003

Honda, M. C., Kusakabe, M., Nakabayashi, S., Manoanini, S. J., and Honjo, S.: Change in $\mathrm{pCO}_{2}$ through biological activity in the marginal seas of the western North Pacific: The efficiency of the biological pump estimated by a sediment Trap experiment, J. Oceanogr., 53, 645-662, 1997.

Honjo, S., Manganini, S. J., Krishfield, R. A., and Francois, R.: Particulate organic carbon fluxes to the ocean interior and factors controlling the biological pump: A synthesis of global sediment trap programs since 1983, Progr. Oceanogr., 76, 217-285, 2008.

Ignatiades, L., Gotsis-Skretas, O., Pagou, K., and Krasakopoulou, E.: Diversification of phytoplankton community structure and related parameters along a large-scale longitudinal east-west transect of the Mediterranean Sea, J. Plankton Res., 31, 411-428, 2009.

Ittekkot, V., Haake, B., Bartsch, M., Nair, R. R., and Ramaswamy, V.: Organic carbon removal in the sea: The continental connection, in: Upwelling Systems: Evolution Since the Early Miocene, edited by: Prell, C. P. and Emeis, K. C., Geological Society Special Publication No. 64, 167-176, 1992.

Kalivitis, N., A. Bougiatioti, A., Kouvarakis, G., and Mihalopoulos, N.: Long term measurements of atmospheric aerosol optical properties in the Eastern Mediterranean, Atmos. Res., 102, 351357, 2011.

Karageorgis, A. P.: Suspended particulate matter distribution at the NESTOR site, using optical methods and bottle data, Km3NeT Collaboration Meeting 16-18 April 2007, Pylos, Greece, 2007.

Karageorgis, A. P., Gardner, W. D., Georgopoulos, D., Mishonov, A.V., Krasakopoulou, E., and Anagnostou, C.: Particle dynamics in the Eastern Mediterranean Sea: a synthesis based on light transmission, PMC, and POC archives (1991-2001), Deep-Sea Res. Pt. I, 55, 177-202, 2008. 
Karageorgis, A. P., Georgopoulos, D., Kanellopoulos, T. D., Mikkelsen, O. A., Pagou, K., Kontoyiannis, H., Pavlidou, A., and Anagnostou, C.: Spatial and seasonal variability of particulate matter optical and size properties in the Eastern Mediterranean Sea, J. Mar. Syst., 105-108, 123-134, 2012.

Karl, D. M., Christian, J. R., Dore, J. E., Hebel, D. V., Letelier, R. M., Tupas, L. M., and Winn, C. D.: Seasonal and interannual variability in primary production and particle flux at station ALOHA, Deep-Sea Res. Pt. II, 43, 539-568, 1996.

Karl, D. M., Dore, J. E., Lukas, R., Michaels, A. F., Bates, N. R., and Knap, A.: Building the long-term picture: The U.S. JGOFS time-series programs, Oceanography, 14, 6-17, 2001.

Kerhervé, P., Heussner, S., Charrière, B., Stavrakakis, S., Ferrand, J. L., Monaco, A., and Delsaut, N.: Biogeochemistry and dynamics of settling particle fluxes at the Antikythira Strait (Eastern Mediterranean), Progr. Oceanogr., 44, 651-675, 1999.

Klaas, C. and Archer, D. E.: Association of sinking organic matter with various types of mineral ballast in the deep sea: Implications for the rain ratio, Global Biogeochem. Cy., 16, 63-61, 2002.

Klein, B., Roether, W., Manca, B. B., Bregant, D., Beitzel, V., Kovacevic, V., and Luchetta, A.: The large deep water transient in the eastern Mediterranean, Deep-Sea Res. Pt. II, 46, 371-414, 1999.

Km3NeT Collaboration: Report on evaluation of existing water, oceanographic, biological and geological data from candidate sites, Km3NeT Report, WP5, Deliverable 5.1, 2007.

Knauer, G. A., Karl, D. M., Martin, J. H., and Hunter, C. N.: In situ effects of selected preservatives on total carbon, nitrogen and metals collected in sediment traps, J. Mar. Res., 42, 445-462, 1984.

Kontoyiannis, H.: The status of the deep hydrography and eddy field during 2006-2009 at the southeast Ionian tentative neutrinotelescope site, 39th CIESM Congress, Venice, Italy, 2010.

Kontoyiannis, H., and Lykousis, V.: Was the East Mediterranean deep thermohaline cell weakening during 2006-2009?, Nucl. Instrum. Meth. A, 626-627, S91-S93, 2011.

Kouvarakis, G., Mihalopoulos, N., Tselepides, A., and Stavrakakis, S.: On the importance of atmospheric inputs of inorganic nitrogen species on the productivity of the Eastern Mediterranean sea, Global Biogeochem. Cy., 15, 805-817, 2001.

Krasakopoulou, E., Souvermezoglou, E., and Goyet, C.: Anthropogenic $\mathrm{CO}_{2}$ fluxes in the Otranto Strait (E. Mediterranean) in February 1995, Deep-Sea Res. Pt. I, 58, 1103-1114, 2011.

Krom, M. D., Kress, N., Brenner, S., and Gordon, L. I.: Phosphorus limitation of primary productivity in the eastern Mediterranean Sea, Limnol. Oceanogr., 36, 424-432, 1991.

Lampitt, R. S. and Antia, A. N.: Particle flux in deep seas: Regional characteristics and temporal variability, Deep-Sea Res. Pt. I, 44, 1377-1403, 1997.

Larnicol, G., Ayoub, N., and Le Traon, P. Y.: Major changes in Mediterranean Sea level variability from 7 years of TOPEX/Poseidon and ERS-1/2 data, J. Mar. Syst., 33-34, 6389, 2002.

Laws, E. A., Falkowski, P. G., Smith Jr, W. O., Ducklow, H., and McCarthy, J. J.: Temperature effects on export production in the open ocean, Global Biogeochem. Cy., 14, 1231-1246, 2000.

Lee, C., Peterson, M. L., Wakeham, S. G., Armstrong, R. A., Cochran, J. K., Miquel, J. C., Fowler, S. W., Hirschberg, D., Beck, A., and Xue, J.: Particulate organic matter and ballast fluxes measured using time-series and settling velocity sediment traps in the northwestern Mediterranean Sea, Deep-Sea Res. Pt. II, 56, 1420-1436, 2009.

Lepore, K., Moran, S. B., Burd, A. B., Jackson, G. A., Smith, J. N., Kelly, R. P., Kaberi, H., Stavrakakis, S., and Assimakopoulou, G.: Sediment trap and in-situ pump size-fractionated POC/ ${ }^{234} \mathrm{Th}$ ratios in the Mediterranean Sea and Northwest Atlantic: Implications for POC export, Deep-Sea Res. Pt. I, 56, 599-613, 2009.

Loÿe-Pilot, M. D., Martin, J. M., and Morelli, J.: Atmospheric input of inorganic nitrogen to the Western Mediterranean, Biogeochemistry, 9, 117-134, 1990.

Lutz, M., Dunbar, R., and Caldeira, K.: Regional variability in the vertical flux of particulate organic carbon in the ocean interior, Global Biogeochem. Cy., 16, 1037, doi:10.1029/2000GB001383, 2002.

Malanotte-Rizzoli, P., Manca, B., Ribera D’Alcala, M., Theocharis, A., Bergamasco, A., Bregant, D., Budillon, G., Civitarese, G., Georgopoulos, D., Michelato, A., Sansone, E., Scarazzato, P., and Souvermezoglou, E.: A synthesis of the Ionian Sea hydrography, circulation and water mass pathways during POEM-Phase I, Progr. Oceanogr., 39, 153-204, 1997.

Malanotte-Rizzoli, P., Manca, B. B., Ribera d'Alcala, M., Theocharis, A., Brenner, S., Budillon, G., and Özsoy, E.: The Eastern Mediterranean in the 80s and in the 90s: The big transition in the intermediate and deep circulations, Dynam. Atmos. Oceans, 29, 365-395, 1999.

Malinverno, E., Triantaphyllou, M. V., Stavrakakis, S., Ziveri, P., and Lykousis, V.: Seasonal and spatial variability of coccolithophore export production at the South-Western margin of Crete (Eastern Mediterranean), Mar. Micropaleontol., 71, 131147, 2009.

Manca, B. B., Budillon, G., Scarazzato, P., and Ursella, L.: Evolution of dynamics in the eastern Mediterranean affecting water mass structures and properties in the Ionian and Adriatic Seas, J. Geophys. Res., 108, 8102, doi:10.1029/2002JC001664, 2003.

Markaki, Z., Oikonomou, K., Kocak, M., Kouvarakis, G., Chaniotaki, A., Kubilay, N., and Mihalopoulos, N.: Atmospheric deposition of inorganic phosphorus in the Levantine Basin, eastern Mediterranean: Spatial and temporal variability and its role in seawater productivity, Limnol. Oceanogr., 48, 1557-1568, 2003.

Markaki, Z., Loÿe-Pilot, M. D., Violaki, K., Benyahya, L., and Mihalopoulos, N.: Variability of atmospheric deposition of dissolved nitrogen and phosphorus in the Mediterranean and possible link to the anomalous seawater N/P ratio, Mar. Chem., 120, 187-194, 2010.

Ternon, E., Guieu, C., Loÿe-Pilot, M.-D., Leblond, N., Bosc, E., Gasser, B., Miquel, J.-C., and Martín, J.: The impact of Saharan dust on the particulate export in the water column of the North Western Mediterranean Sea, Biogeosciences, 7, 809-826, doi:10.5194/bg-7-809-2010, 2010.

Martin, J. H., Knauer, G. A., Karl, D. M., and Broenkow, W. W.: VERTEX: carbon cycling in the northeast Pacific, Deep-Sea Res. Pt. I, 34, 267-285, 1987.

Martin, J., Miquel, J. C., and Khripounoff, A.: Impact of open sea deep convection on sediment remobilization in the western Mediterranean, Geophys. Res. Lett., 37, L13604, doi:10.1029/2010GL043704, 2010.

Mazzocchi, M. G., Nervegna, D., D’Elia, G., Di Capua, I., Aguzzi, L., and Boldrin, A.: Spring mesozooplankton com- 
munities in the epipelagic Ionian Sea in relation to the Eastern Mediterranean Transient, J. Geophys. Res., 108, 8114, doi:10.1029/2002JC001640, 2003.

Meador, T. B., Gogou, A., Spyres, G., Herndl, G. J., Krasakopoulou, E., Psarra, S., Yokokawa, T., De Corte, D., Zervakis, V., Repeta, D. J.: Biogeochemical relationships between ultrafiltered dissolved organic matter and picoplankton activity in the Eastern Mediterranean Sea, Deep-Sea Res. Pt. II, 57, 1460-1477, 2010.

Miquel, J. C., Martín, J., Gasser, B., Rodriguez-y-Baena, A., Toubal, T., and Fowler, S. W.: Dynamics of particle flux and carbon export in the northwestern Mediterranean Sea: A two decade time-series study at the DYFAMED site, Progr. Oceanogr., 91, 461-481, 2011.

Monaco, A., Durrieu de Madron, X., Radakovitch, O., Heussner, S., and Carbonne, J.: Origin and variability of downward biogeochemical fluxes on the Rhone continental margin (NW Mediterranean), Deep-Sea Res. Pt. I, 46, 1483-1511, 1999.

Mortlock, R. A. and Froelich, P. N.: A simple method for the rapid determination of biogenic opal in pelagic marine sediments, Deep-Sea Res., 36, 1415-1426, 1989.

Moutin, T. and Raimbault, P.: Primary production, carbon export and nutrients availability in western and eastern Mediterranean Sea in early summer 1996 (MINOS cruise), J. Mar. Syst., 33-34, 273-288, 2002.

Moulin, C., Lamber, C. E., Dayan, U., Masson, V., Ramone, M., Bousque, P., Legrand, M., Balkanski, Y., Guellel, W., Marticorena, B. Bergametti, G., and Dulac, F.: Satellite climatology of African dust transport in the Mediterranean atmosphere, J. Geophys. Res., 103, 13137-13144, 1998.

Nieuwenhuize, J., Maas, Y. E. M., and Middelburg, J. J.: Rapid analysis of organic carbon and nitrogen in particulate materials, Mar. Chem., 45, 217-224, 1994.

Nittis, K., Pinardi, N., and Lascaratos, A.: Characteristics of the summer 1987 flow field in the Ionian Sea, J. Geophys. Res., 98, 10171-10184, 1993.

Özsoy, E., Kubilay, N., Nickovic, S., and Moulin C.: A hemisphere dust storm affecting the Atlantic and Mediterranean in April 1994: Analyses, modeling, ground-based measurements and satellite observations, J. Geophys. Res., 106, 18439-18460, 2001

Pace, M. L., Knauer, G. A., Karl, D. M., and Martin, J. H.: Primary production, new production and vertical flux in the eastern Pacific Ocean, Nature, 325, 803-804, 1987.

Pasqual, C., Sanchez-Vidal, A., Zúñiga, D., Calafat, A., Canals, M., Durrieu de Madron, X., Puig, P., Heussner, S., Palanques, A., and Delsaut, N.: Flux and composition of settling particles across the continental margin of the Gulf of Lion: the role of dense shelf water cascading, Biogeosciences, 7, 217-231, doi:10.5194/bg-7217-2010, 2010.

Passow, U.: Switching perspectives: Do mineral fluxes determine particulate organic carbon fluxes or vice versa?, Geochem. Geophys. Geosy., 5, 1-5, doi:10.1029/2003gc000670, 2004.

Passow, U., Shipe, R. F., Murray, A., Pak, D. K., Brzezinski, M. A., and Alldredge, A. L.: Origin of transparent exopolymer particles (TEP) and their role in the sedimentation of particulate matter, Cont. Shelf Res., 21, 327-346, 2001.

Patara, L., Pinardi, N., Corselli, C., Malinverno, E., Tonani, M., Santoleri, R., and Masina, S.: Particle fluxes in the deep East- ern Mediterranean basins: the role of ocean vertical velocities, Biogeosciences, 6, 333-348, doi:10.5194/bg-6-333-2009, 2009.

Polymeris G. S., George Kitis, Liolios, A. K., Sakalis, A., Zioutas, K., Anassontzis, E. G., and Tsirliganis, N. C.: Luminescence dating of the top of a deep water core from the NESTOR site near the Hellenic Trench, east Mediterranean Sea, Quat. Geochronol., 4, 68-81, 2009.

Rabitti, S., Bianchi, F., Boldrin, A., Da Ros, L., Socal, G. and Totti, C.: Particulate matter and phytoplankton in the Ionian Sea, Oceanol. Acta, 17, 297-307, 1994.

Ridame, C. and Guieu, C.: Saharan input of phosphate to the oligotrophic water of the open western Mediterranean sea, Limnol. Oceanogr., 47, 856-869, 2002.

Sabine, C. L. and Tanhua, T.: Estimation of anthropogenic $\mathrm{CO}_{2}$ inventories in the ocean, Annu. Rev. Mar. Sci., 2, 175-198, 2010.

Sanchez-Vidal, A., Calafat, A., Canals, M., and Fabres, J.: Particle fluxes in the Almeria-Oran Front: control by coastal upwelling and sea surface circulation, J. Mar. Syst., 52, 89-106, 2004.

Sanchez-Vidal, A., Calafat, A., Canals, M., Frigola, J., and Fabres, J.: Particle fluxes and organic carbon balance across the Eastern Alboran Sea (SW Mediterranean Sea), Cont. Shelf Res., 25, 609628, 2005.

Schneider, A., Tanhua, T., Krtzinger, A., and Wallace, D. W. R.: High anthropogenic carbon content in the eastern Mediterranean, J. Geophys. Res., 115, C12050, doi:10.1029/2010jc006171, 2010.

Siegenthaler, U. and Sarmiento, J. L.: Atmospheric carbon dioxide and the ocean, Nature, 365, 119-125, 1993

Siokou-Frangou, I., Christaki, U., Mazzocchi, M. G., Montresor, M., Ribera d'Alcalá, M., Vaqué, D., and Zingone, A.: Plankton in the open Mediterranean Sea: a review, Biogeosciences, 7, 15431586, doi:10.5194/bg-7-1543-2010, 2010.

Stavrakakis, S. and Lykousis, V.: Interannual mass flux variations of settling particles in the NESTOR basins, SE. Ionian Sea (E. Mediterranean), Greece, Nucl. Instrum. Meth. A, 626-627, S99S101, doi:10.1016/j.nima.2010.04.076, 2011.

Stavrakakis, S., Chronis, G., Tselepides, A., Heussner, S., Monaco, A., and Abassi, A.: Downward fluxes of settling particles in the deep Cretan Sea (NE Mediterranean), Progr. Oceanogr., 46, 217 240, 2000.

Suess, E.: Particulate organic carbon flux in the oceans - Surface productivity and oxygen utilization, Nature, 288, 260-263, 1980.

Taillandier, V., D'Ortenzio, F., and Antoine, D.: Carbon fluxes in the mixed layer of the Mediterranean Sea in the 1980s and the 2000s, Deep-Sea Res. Pt. I, 65, 73-84, 2012.

Takahashi, K., Fujitani, N., Yanada, M., and Maita, Y.: Long-term biogenic particle fluxes in the Bering Sea and the central subarctic Pacific Ocean, 1990-1995, Deep-Sea Res. Pt. I, 47, 17231759, 2000.

Takahashi, K., Fujitani, N., and Yanada, M.: Long term monitoring of particle fluxes in the Bering Sea and the central subarctic Pacific Ocean, 1990-2000, Progr. Oceanogr., 55, 95-112, 2002.

Theocharis, A., Nittis, K., Kontoyiannis, H., Papageorgiou, M., and Balopoulos, E.: Climatic changes in the Aegean Sea influence the Eastern Mediterranean thermohaline circulation (19861997), Geophys. Res. Lett., 26, 1617-1620, 1999.

Theodosi, C., Parinos, C., Gogou, A., Kokotos, A., Stavrakakis, S., Lykousis, V., Hatzianestis, J., and Mihalopoulos, N.: Downward fluxes of elemental carbon, metals and polycyclic aro- 
matic hydrocarbons in settling particles from the deep Ionian Sea (NESTOR site), Eastern Mediterranean, Biogeosciences, 10, 4449-4464, doi:10.5194/bg-10-4449-2013, 2013.

Thingstad, T. F. and Rassoulzadegan, F.: Nutrient limitations, microbial food webs, and biological C-pumps: Suggested interactions in a P-limited Mediterranean, Mar. Ecol.-Prog. Ser., 117, 299-306, 1995.

Touratier, F. and Goyet, C.: Impact of the Eastern Mediterranean Transient on the distribution of anthropogenic $\mathrm{CO}_{2}$ and first estimate of acidification for the Mediterranean Sea, Deep-Sea Res. Pt. I, 58, 1-15, 2011.

Triantaphyllou, M. V., Ziveri, P., and Tselepides, A.: Coccolithophore export production and response to seasonal surface water variability in the oligotrophic Cretan Sea (NE Mediterranean), Micropaleontology, 50, 127-144, 2004.

Trimonis, E. and Rudenko, M.: Geomorphology and bottom sediments of the Pylos area. In: Proceedings of the 2nd NESTOR International Workshop, edited by: Resvanis, L. K., p. 321, 1992.

Verardo, D. J., Froelich, P. N., and McIntyre, A.: Determination of organic carbon and nitrogen in marine sediments using the Carlo Erba NA-1500 Analyzer, Deep-Sea Res., 37, 1, 157-165, 1990.

Verdugo, P., Alldredge, A. L., Azam, F., Kirchman, D. L., Passow, U., and Santschi, P. H.: The oceanic gel phase: a bridge in the DOM-POM continuum, Mar. Chem., 92, 67-85, 2004.
Volk, T. and Hoffert M.: Ocean carbon pumps: Analysis of relative strengths and efficiencies in ocean-driven atmospheric $\mathrm{CO}_{2}$ changes, in: The Carbon Cycle and Atmospheric $\mathrm{CO}_{2}$ : Natural Variations Archean to Present, Geophys. Monogr. Ser., vol. 32, edited by: Sundquist, E. T. and Broecker, W. S., AGU, Washington, DC, 99-110, doi:10.1029/GM032p0099, 1985.

Wong, C. S., Whitney, F. A., Crawford, D. W., Iseki, K., Matear, R. J., Johnson, W. K., Page, J. S., and Timothy, D.: Seasonal and interannual variability in particle fluxes of carbon, nitrogen and silicon from time series of sediment traps at Ocean Station P, 1982-1993: Relationship to changes in subarctic primary productivity, Deep-Sea Res. Pt. II, 46, 2735-2760, 1999.

Yokokawa, T., De Corte, D., Sintes, E., and Gerndl, G. J.: Spatial patterns of bacterial abundance, activity and community composition in relation to water masses in the Eastern Mediterranean Sea, Aquat. Microb. Ecol., 59, 185-195, 2010.

Zúñiga, D., Calafat, A., Sanchez-Vidal, A., Canals, M., Price, B., Heussner, S., and Miserocchi, S.: Particulate organic carbon budget in the open Algero-Balearic Basin (Western Mediterranean): Assessment from a one-year sediment trap experiment, Deep-Sea Res. Pt. I, 54, 1530-1548, 2007. 